\title{
Powstaniec, dziennikarz, opozycjonista. Szkic o Jerzym Zieleńskim
}

\section{JAN OLASZEK}

Instytut Studiów Politycznych

Polskiej Akademii Nauk Instytut Pamięci Narodowej ORCID: 0000-0002-7700-3256
Jerzy Zieleński, w latach sześćdziesiątych i siedemdziesiątych XX wieku znany dziennikarz, obecnie należy do postaci niemal zupełnie zapomnianych. Przypomina się o nim właściwie jedynie przy okazji kolejnych rocznic wprowadzenia stanu wojennego i niemal wyłącznie w kontekście jego samobójczej śmierci, która miała miejsce właśnie 13 grudnia 1981 roku. 0 jego życiu i dorobku dziennikarskim wspomina się natomiast bardzo zdawkowo. Zieleński dotychczas nie cieszył się zresztą większym zainteresowaniem nie tylko mediów, ale również historyków, prasoznawców i badaczy innych specjalności. Lista publikacji jemu poświęconych ogranicza się (poza kilkoma tekstami wspomnieniowymi) do suchych biogramów ${ }^{1}$. Celem tego artykułu jest zarysowanie drogi życiowej Zieleńskiego, wskazanie jej najważniejszych etapów oraz charakterystyka jego twórczości.

Zainteresowanie tymi kwestiami jest uzasadnione przynajmniej z dwóch powodów. Jerzy Zieleński był jednym z kilku zawodowych dziennikarzy, którzy już w latach siedemdziesiątych zdecydowali się na współpracę z demokratyczną opozycją i publikowanie w niezależnej prasie. Jego życie zasługuje na opisanie również dlatego, że odbija się w nim wiele istotnych zjawisk z dwudziestowiecznej historii Polski. Można wśród nich wymienić traumatyczne doświadczenia niemieckiej okupacji, powojenne dylematy uczestników akowskiej konspiracji, problem przystosowania się do tworzonego przez komunistów ustroju oraz narodziny opozycji demokratycznej i Solidarności. Jego biografia jest interesująca jako przykład losów przedstawicieli pokolenia, które wchodziło w dorosłość w czasie II wojny światowej lub niedługo po jej zakończeniu, co w istotnej mierze wpłynęło na ich całe dalsze życie i dokonywane wybory.

Artykuł nie aspiruje do tego, by w pełni przedstawić biografię Jerzego Zieleńskiego i jego dorobek. Skoncentrowałem się na politycznych aspektach jego biografii i twórczości, mniej miejsca poświęcając na przykład jego tekstom popularyzującym naukę i reportażom z podróży w odległe części świata. Poza obszarem moich zainteresowań pozostaje również życie prywatne bohatera tekstu, na temat którego podaję

1. Zob. przykładowe biogramy: E. Ciborowska, Leksykon polskiego dziennikarstwa, Warszawa 2002, s. 652; W. Domagalski, Jerzy Zieleński, https://encysol.pl/es/encyklopedia/biogramy/19695,ZielenskiJerzy.html?search $=5172117400$. 
jedynie najważniejsze informacje, potrzebne do zrozumienia innych sfer jego życia. Podstawę źródłową niniejszego szkicu, oprócz publikacji samego Zieleńskiego, stanowią dzienniki i wspomnienia osób, które go znały, materiały z archiwów prywatnych członków jego rodziny, Archiwum Instytutu Pamięci Narodowej i Archiwum Uniwersytetu Warszawskiego oraz pojedyncze dokumenty przechowywane w Archiwum Akt Nowych i Archiwum Ośrodka KARTA. Wykorzystałem również zebrane przeze mnie relacje członków jego rodziny, przyjaciół i współpracowników.

\section{Doświadczenia wojenne}

Jerzy Zieleński urodził się 16 października 1928 roku w Łodzi. Jego rodzicami byli Kornel Zieleński i Wanda z domu Szaad. W 1931 roku przenieśli się oni do Poznania. Ojciec przyszłego dziennikarza pracował jako architekt, matka zaś jako pomoc biurowa w tamtejszej fabryce akumulatorów "Centra"2. W przekazie rodzinnym Jerzy został zapamiętany jako dziecko raczej introwertyczne i bardzo wrażliwe. Od bardzo wczesnego wieku fascynował się pisaniem. Członkowie rodziny, znając jego upodobania, zostawiali mu w różnych miejscach potrzebne do tego kartki. On zapisywał na nich dziecięce opowiadania i wierszyki. Gdy nie miał pod ręką żadnej kartki, zdarzało mu się użyć zamiast niej serwetki Ta pasja towarzyszyła mu przez całe życie.

We wrześniu 1939 roku, po ataku Niemiec na Polskę, Zieleńscy próbowali uciekać na wschód, jednak udało im się dotrzeć jedynie do pobliskiej Wrześni, gdzie mieszkała ich dalsza rodzina. Dalszą drogę odcięły im bowiem wojska III Rzeszy. Jedenastoletni Jerzy trafił następnie do swojego stryja, Kazimierza Zieleńskiego, który mieszkał w majątku
Katarzynki koło Swarzędza. Jego rodzice wrócili wówczas do Poznania, Jerzy zaś dołączył do nich po kilku tygodniach. Kornel Zieleński po pewnym czasie zatrudnił się w Poznaniu w jednej z niemieckich firm, a jego żona, dzięki temu, że biegle mówiła po niemiecku, mogła kontynuować pracę w "Centrze". W maju 1941 roku Zieleńscy zdecydowali się opuścić wcieloną do III Rzeszy Wielkopolskę, gdzie Polacy byli narażeni na represje jeszcze bardziej niż na terenie Generalnego Gubernatorstwa. Udali się do Warszawy, gdzie mieszkała rodzina Wandy Zieleńskiej. Nie uchroniło ich to jednak przed represjami. W czerwcu 1943 roku piętnastoletni Jerzy Zieleński został zatrzymany przez Niemców w łapance na placu Trzech Krzyży, po czym spędził sześć tygodni w budzącym wówczas grozę więzieniu zwanym Pawiakiem ${ }^{4}$. Dzięki znajomościom jego matki udało się doprowadzić do wypuszczenia Jerzego na wolność 5 . Wszystko wskazuje na to, że nie był tam bity ani poddawany torturom, ale sam pobyt $\mathrm{w}$ takim miejscu dla piętnastoletniego chłopca musiał być traumatycznym przeżyciem, które mogło rzutować na dokonywane przez niego w dalszym życiu wybory.

Po wyjściu Jerzego na wolność zdecydowano o wysłaniu go dla bezpieczeństwa do szkoły rolniczej w Pszczelnie koło Brwinowa (wcześniej naukę w szkole powszechnej udało mu się dokończyć w Warszawie, w ramach tajnych kompletów). Nauka w podwarszawskiej wsi sprowadzała się głównie do pracy na roli. Jednocześnie pobyt tam był okazją do nawiązania nowych kontaktów z rówieśnikami. od poznanych w Pszczelnie kolegów Zieleński dostał propozycję wstąpienia do konspiracyjnej organizacji harcerskiej o nazwie "Zawiszacy", która miała wchodzić w skład Szarych Szeregów. Szybko jednak grupa ta się rozpadła. Był to jednak dopiero początek

2. Archiwum Instytutu Pamięci Narodowej w Warszawie [dalej: AIPN], 00191/157, Odpis ankiety personalnej Jerzego Zieleńskiego, [1951], k. 23; ibidem, Życiorys Jerzego Zieleńskiego, [1951], k. 27; Zbiory prywatne Bogumiły Zieleńskiej, B. Zieleńska, Jerzy Zieleński, publicysta, maszynopis.

3. Relacje Barbary Zieleńskiej (2019) i Bogumiły Zieleńskiej (2020).

4. AIPN, 00191/157, Życiorys Jerzego Zieleńskiego, [1951], k. 27; relacja Bogumiły Zieleńskiej (2020).

5. Relacje Barbary Zieleńskiej (2019) i Bogumiły Zieleńskiej (2020). 
konspiracyjnych doświadczeń bohatera tego tekstu. Po powrocie do Warszawy Zieleński poznał nieco starszego od siebie Witolda Piaseckiego, członka konspiracyjnej organizacji Harcerstwo Polskie. Podlegała ona Narodowej Organizacji Wojskowej, czyli odłamowi konspiracji wywodzącemu się z endecji. Nic nie wiadomo o tym, żeby rodzina Zieleńskiego miała cokolwiek wspólnego z tym nurtem politycznym, ale nie przeszkadzało to Jerzemu wstąpić do Harcerstwa Polskiego. Nie było to zresztą niczym dziwnym - w konspiracji często o przynależności do danej struktury decydował przypadkowo nawiązany kontakt, a nie wspólnota poglądów politycznych. Najważniejsze było, żeby działać w podziemiu, a to, pod jakim szyldem się to robi, nie miało większego znaczenia. Jerzy Zieleński wstąpił do Harcerstwa Polskiego w lipcu 1944 roku, w związku z czym jego działalność konspiracyjna przed wybuchem powstania warszawskiego nie mogła trwać długo. Zdążył jedynie przejść szkolenie z zakresu łączności i wziąć udział w akcji rozwieszenia ulotek ${ }^{6}$.

Tuż przed wybuchem powstania szesnastoletni Jerzy Zieleński doświadczył kolejnego traumatycznego przeżycia. Jego matka zginęła w wypadku tramwajowym na placu Narutowicza. Mimo to wziął udział w powstaniu jako łącznik przy dowództwie rejonu pułku podpułkownika Stanisława Błaszczaka „Roga", które znajdowało się na placu Żelaznej Bramy (w Śródmieściu), a następnie w plutonie łączności 4. Kompanii "Harcerskiej” batalionu NOW-AK "Gustaw" na Starym Mieście i w Śródmieściu”. W konspiracji nosił pseudonim „Wolański"8. Wybuch bomby przy ulicy Świętokrzyskiej, do którego doszło 7 września, sprawił, że Jerzy został zasypany gruzami. Na skutek tego przez pewien czas nie mógł chodzić, co wyłączyło go z dalszego udziaŁu w walkach. W kolejnych tygodniach przebywał w powstańczym szpitalu przy ulicy Chmielnej, a następnie w mieszkaniu swojej ciotki Marii Szaad. Po kapitulacji Warszawy Jerzy Zieleński i jego ojciec znaleźli się w dużej grupie ludności cywilnej, która została wyprowadzona $\mathrm{z}$ doszczętnie zrujnowanego miasta. Poganiani przez Niemców warszawiacy musieli iść piechotą do leżącego wówczas poza granicami stolicy Ursusa, skąd wywożono ich do obozu przejściowego. W dniu transportu Kornelowi i Jerzemu Zieleńskim udało się zbiec. Dostali się do Wolbromia. Tam ukrywali się przez dwa tygodnie, by następnie udać się do Radomia, gdzie przebywał stryj Jerzego, Kazimierz Zieleński. Kornel zaczął tam wówczas pracę w biurze technicznym, a Jerzy zatrudnił się jako goniec. W styczniu 1945 roku obaj przez Warszawę wrócili do rodzinnego Poznania9.

\section{Powojenne dylematy}

Ludzie o podobnych do Jerzego Zieleńskiego życiorysach wobec powojennej rzeczywistości przyjmowali rozmaite postawy. Dla jednych liczyło się przede wszystkim to, że wojna się skończyła i odradza się Polska; dla innych nie do zaakceptowania było to, że nie będzie to Polska wolna, tylko państwo podległe ZSRR, jak się szybko okazało - o komunistycznym ustroju. Jedni konspiratorzy włączali się w tworzenie nowego państwa, inni kontynuowali działalność podziemną. Zieleński w latach powojennych przechodził ewolucję. Początkowo próbował angażować się w antykomunistyczną konspirację. "W owym czasie byłem nastawiony wrogo do obecnej rzeczywistości. Wyniosłem to zarówno z rodziny, jak i z podziemnych organizacji, w których byłem w czasie okupacji" - wspominał w życiorysie sporządzonym kilka lat później ${ }^{10}$. Ów dokument jest jedynym źródłem informacji na te-

6. AIPN, 00191/157, Życiorys Jerzego Zieleńskiego, [1951], k. 27.

7. Ibidem; www.1944.pl/powstancze-biogramy/jerzy-zielenski,51932.html (dostęp: 19.06.2020).

8. B. Zieleńska, Jerzy Zieleński, publicysta.

9. AIPN, 00191/157, Życiorys Jerzego Zieleńskiego, [1951], k. 27-28.

10. Ibidem, k. 28. 
mat konspiracyjnych działań Zieleńskiego z tego czasu. W ogólnym zarysie wydaje się on wiarygodny, jednak trzeba wziąć pod uwagę, że powstawał w szczególnych okolicznościach. Zieleński przedstawił go na żądanie funkcjonariuszy Urzędu Bezpieczeństwa (o tym, dlaczego tak się stało, będzie jeszcze mowa). Sposób, w jaki mówił o swoich działaniach i motywacjach, mógł wynikać z presji, której został wówczas poddany. Z tego dokumentu wynika, że w tym czasie Zieleński wraz z dwoma kolegami zbierali amunicję w poznańskich fortach i bunkrach. Poszukiwali też kontaktu z jakimiś młodzieżowymi organizacjami konspiracyjnymi. Od jednego z kolegów Zieleński otrzymał wówczas na przechowanie pistolet (popularną ",belgijkę”, czyli browninga FN 1910). Jego działalność w tej grupie sprowadzała się do dwukrotnego rozrzucenia ulotek na terenie szkoły, w której kontynuował naukę. Niezależnie od tego nawiązał kontakty z młodymi ludźmi, którzy wcześniej tak jak on byli związani ze strukturami Narodowej Organizacji Wojskowej. Zieleński należał wówczas do Związku Harcerstwa Polskiego, który działał w pełni oficjalnie i legalnie, ale według późniejszych słów Zieleńskiego miała tam panować atmosfera sprzeciwu wobec władzy komunistycznej ${ }^{11}$.

Około 1947 roku nastawienie Jerzego Zieleńskiego uległo zmianie. Wówczas pozbył się wspomnianego pistoletu. Później jeszcze tylko był namawiany przez szkolnego kolegę, Andrzeja Skowrońskiego, i sąsiada o nazwisku Kłoś do stworzenia organizacji nawiązującej do tradycji NOW, z którymi wszyscy trzej byli wcześniej związani. Jednak nic $\mathrm{z}$ tego nie wyniknęło. Zieleński, tłumacząc swoją przemianę, wskazywał na wstrząs, jakim było dla niego zabicie przez jednego z jego kolegów ze szkoły działacza Związku Walki Młodych. „Poczułem obrzydzenie do tych metod" - oceniał po kilku latach $^{12}$. Można zapytać, czy mówiąc tak w 1951 roku, szczerze opisywał swoje wcześniejsze motywacje. Nie można wykluczyć, że znaczenie miała sytuacja, w której znajdował się, wypowiadając te słowa, czyli rozmowa z funkcjonariuszami UB. Tak wyraźne odcięcie się od powojennego podziemia mogło być elementem pewnej strategii działania w trudnej sytuacji. Jednocześnie jednak nie ma wątpliwości co do tego, że Jerzy Zieleński około 1947 roku zmienił swój stosunek do odradzającej się rzeczywistości. Wpływ na to mogło mieć poczucie bezsensowności dalszej walki, radość z postępującej odbudowy kraju (niezależnie od jego ustroju), chęć skupienia się na prywatnych sprawach czy też poparcie dla zachodzących przemian społecznych. Wszystko są to przypuszczenia, Zieleński bowiem nigdzie nie opisał swoich poglądów z tamtych lat. Dodatkowe utrudnienie wynika $z$ tego, że niechętnie wracał do przeszłości nawet w rozmowach z najbliższymi. Dziennikarka Janina Jankowska, która w latach siedemdziesiątych blisko przyjaźniła się z Zieleńskim i rozmawiała z nim o przeszłości, wspominała, że miał głębokie poczucie porażki związanej z udziałem w powstaniu warszawskim i tym, co stało się z wieloma jego kolegami. Jej zdaniem niemała część tego pokolenia przyjęła ideologię wprowadzaną w Polsce po wojnie, ponieważ przynosiła ona jednoznaczne wytłumaczenie przyczyn porażki i wskazywała na to, kto jest za nią odpowiedzialny. W myśl tego przekazu ludzie tacy jak Zieleński mieli być ofiarami wielkiego oszustwa. Według Jankowskiej wpływ na postawę bohatera tego tekstu znaczenie miało też, że ideologia komunistyczna młodym ludziom, którzy doświadczyli wojny, na nowo tłumaczyła świat ${ }^{13}$. Dodać warto, że tego rodzaju myślenie nie było obce ludziom, którzy zdawali sobie sprawę ze zbrodniczości komunizmu w ZSRR, gdyż tłumaczyli sobie, że w Polsce proces tworzenia takiego ustroju będzie wyglądał inaczej. Przystosowanie się ludzi aktywnych przez krótki czas po wojnie

\footnotetext{
11. Ibidem.

12. Ibidem.

13. Relacja Janiny Jankowskiej (2020).
} 
w podziemiu do panujących warunków, a nawet zaangażowanie po stronie tworzącego się systemu nie było zjawiskiem tak rzadkim, jak wynikałoby z czarno-białej narracji o "żołnierzach wyklętych". Jedną z najbardziej znanych takich historii jest los Tadeusza Konwickiego, który po okresie działania w antykomunistycznej konspiracji na Wileńszczyźnie zaangażował się w budowę ustroju komunistycznego, stając się jednym z czołowych pisarzy socrealistycznych z pokolenia "pryszczatych" (by później, tak jak Zieleński, znaleźć się w demokratycznej opozycji). Historia Jerzego Zieleńskiego wpisywała się zatem w doświadczenie większej grupy środowisk akowskich.

Znaczenie dla zaangażowania Zieleńskiego po stronie władzy mogło mieć również to, że rządzona przez komunistów Polska dawała młodym ludziom, którzy decydowali się zaangażować politycznie, możliwość bardzo szybkiej realizacji swoich ambicji zawodowych, często jeszcze w trakcie studiów. Po zdaniu matury w 1947 roku w Liceum Ogólnokształcącym dla Dorosłych w Poznaniu Jerzy Zieleński przeniósł się do Warszawy, gdzie rozpoczął studia dziennikarskie w Akademii Nauk Politycznych. Wstąpił wówczas do Związku Niezależnej Młodzieży Socjalistycznej, organizacji bliskiej Polskiej Partii Socjalistycznej. W lipcu 1948 roku przestała ona istnieć po włączeniu jej do Związku Akademickiego Młodzieży Polskiej. Jerzy Zieleński działał również w tej organizacji, podobnie jak w Związku Młodzieży Polskiej ${ }^{14}$. W cytowanym życiorysie następująco opisywał mającą w nim zajść przemianę: „Sądziłem, że ZMNS jest organizacją rewolucyjną - szczerze. Potem w ZMP zrozumiałem, że był to frazes". Stwierdzał też, że dopiero później zrozumiał "całą ohydę" swojego postępowania15. Nowe państwo potrzebowało kadr dziennikarskich, dlatego nawet ktoś, kto dopiero rozpoczął studia dziennikarskie, mógł pracować w poważnej gazecie. Pamiętać przy tym trzeba, jaką rolę odgrywały gazety w rozpoczynającym się wówczas okresie stalinowskim. Właściwie całość prasy i jej przekazu podporządkowana była funkcjom ideologicznym i propagandowym. Siłą rzeczy dziennikarze publikujący w tym czasie uczestniczyli w legitymizowaniu systemu i szerzeniu panującej w nim ideologii. Praktycznie wszystkie publikowane teksty musiały mieć „słuszną" wymowę, nawet jeśli dotyczyły tematów pozornie apolitycznych. Zieleński pracę dziennikarską rozpoczął już w styczniu 1948 roku jako reporter działu miejskiego "Gazety Ludowej", która wówczas przestała mieć opozycyjny charakter. W sierpniu tego samego roku przeniósł się do czasopisma "Razem”, gdzie pisywał między innymi felietony. W grudniu 1948 roku został zastępcą redaktora naczelnego pisma "Wiadomości Służby Polsce", organu prasowego organizacji o charakterze paramilitarnym, której członkowie uczestniczyli w odbudowywaniu Warszawy i budowie nowo powstających ośrodków przemysłowych. W maju 1950 roku Zieleński trafił do redakcji najważniejszego wówczas pisma młodzieżowego, czyli „Sztandaru Młodych". Przez kolejne dwa lata pracował tam jako reporter ${ }^{16}$. W roku 1951 został członkiem Stowarzyszenia Dziennikarzy Polskich oraz Związku Zawodowego Dziennikarzy $\mathrm{RP}^{17}$. Szybkie zdobycie cenzusu zawodowego dziennikarza zapewne wpłynęło na stosunek do otaczającej go rzeczywistości.

Kolejne lata w życiu Zieleńskiego stały pod znakiem nie tylko łączonej ze studiami kariery dziennikarskiej, ale również ważnych wydarzeń w życiu prywatnym. W styczniu 1951 roku wziął on ślub z Krystyną Szwedówną, również początkującą dziennikarką. Chociaż w 1949 roku wraz z siostrą

14. AIPN, 00191/157, Życiorys Jerzego Zieleńskiego, [1951], k. 28; Archiwum Uniwersytetu Warszawskiego [dalej AUW], 20937, Życiorys Jerzego Zieleńskiego, [1949], bp.

15. AIPN, 00191/157 Życiorys Jerzego Zieleńskiego, [1952], k. 28.

16. B. Zieleńska, Jerzy Zieleński, publicysta; AIPN, 00191/157, Odpis ankiety personalnej Jerzego Zieleńskiego, [1951], k. 23.

17. E. Ciborska, Leksykon..., s. 652; B. Zieleńska, Jerzy Zieleński, publicysta. 
została aresztowana za udział w manifestacji ulicznej w Bielsku-Białej ${ }^{18}$, później podobnie jak Jerzy Zieleński zmieniła swój stosunek do ustroju. Kiedy poznała Zieleńskiego, była zatrudniona w Komendzie Głównej „Służby Polsce”. Jeszcze w 1951 roku Zieleńskim urodził się syn Julian Sergiusz. Dwa lata później urodziła się pierwsza córka, Małgorzata, w 1954 syn Wojciech (który bardzo szybko zmarł), a po dwóch kolejnych córka Barbara. Od 1954 roku rodzina mieszkała w trzypokojowym mieszkaniu przy ulicy Dzielnej ${ }^{19}$.

Można powiedzieć, że biorąc pod uwagę wiek Zieleńskiego, jego kariera dziennikarska rozwijała się bardzo dynamicznie. Jego młodszy kolega ze studiów, znany reportażysta Krzysztof Kąkolewski, wspominał po latach: "Na początku października 1949 r. w Akademii Nauk Politycznych, która działała częściowo według przedwojennych programów i miała wkrótce ulec likwidacji moi koledzy z pierwszego roku powiedzieli mi, że na II roku jest pewien niezwykły kolega, którego muszę poznać. Uległem temu - osobliwemu nawet jak na pełne bezpośredniości stosunki studenckie, wezwaniu, czując, że musi być w tym coś wyjątkowego. Na korytarzu siedział otoczony tłumkiem adorujących go kolegów 21-letni podówczas Jerzy Zieleński, jak mi zaraz powiedziano, najmłodszy redaktor naczelny w Polsce, co prawda małego pisma, ale przede wszystkim jest to człowiek rokujący wielką przyszłość. Uderzyła mnie: jego świetlista prawie radosność, bezpośredniość i rzadka u ludzi błyskawiczność reakcji, wskazująca zarówno na nadspostrzegawczość, jak i na nadwrażliwość" 20 . Słowa te zostały napisane po latach we wspomnieniu o zmarłym koledze, w związku z czym w ich tonie może pobrzmiewać pewna idealizacja, ale wydaje się, że dobrze oddają one charakter Zieleńskiego. Nieprecyzyjna jest informacja o jego funkcji - nie był redaktorem naczelnym, ale zastępcą redaktora naczelnego wspomnianych już "Wiadomości Służby Polsce" (został nim zresztą dopiero w grudniu, a więc nieco później, niż wynikałoby z relacji Kąkolewskiego). Akademia Nauk Politycznych została pod koniec 1950 roku przekształcona w Główną Szkołę Służby Zagranicznej, w której nie było już kierunku dziennikarstwo. W jego miejsce utworzono Sekcję Dziennikarstwa na Wydziale Humanistycznym Uniwersytetu Warszawskiego ${ }^{21}$. Tam Zieleński kontynuował studia ${ }^{22}$.

W cytowanym wspomnieniu Kąkolewskiego szczególnie interesujący jest fragment dotyczący okoliczności rozstania się Jerzego Zieleńskiego ze "Sztandarem Młodych” w maju 1952 roku: „Spoza redakcji «Sztandaru Młodych» przyszedł rozkaz bezzwłocznego zwolnienia jednego z najzdolniejszych, a może najzdolniejszego $\mathrm{z}$ nas, $\mathrm{w}$ dodatku człowieka, który potrafił prawie co dzień dostarczyć materiału gazecie. Nie chodziło tu o tematy - Zieleński poświęcał swój talent przede wszystkim opisowi odradzającej się Warszawy - ale o bliżej niesprecyzowane i nigdzie nie postawione zarzuty. Część udało mi się odtworzyć w czasie następnych wydarzeń, do których zaraz przejdę. Tymczasem Jerzy był bez pracy; jednak ze względu na sytuację rodzinną, starania kolegów i coś jakby cień wstydu, który ogarnął tych, którzy wykonali w redakcji wyrok na nim, dostał pracę w sześciorzędnym dwutygodniku"23. Pismem tym był „Przyjaciel Żołnierza”, w którym Zieleński rozpoczął pracę w marcu 1953 roku $^{24}$.

18. AIPN, 00191/157, Życiorys Jerzego Zieleńskiego, [1952], k. 28; List Barbary Zieleńskiej do Jana Olaszka (2020).

19. Relacja Barbary Zieleńskiej (2019).

20. Zbiory prywatne Barbary Zieleńskiej, Wspomnienie Krzysztofa Kąkolewskiego o Jerzym Zieleńskim, maszynopis, s. 1.

21. T. Rutkowski, Na styku nauki i polityki. Uniwersytet Warszawski w PRL 1944-1989, [w:] Dzieje Uniwersytetu Warszawskiego po 1945 roku, red. P.M. Majewski, Warszawa 2016, s. 420.

22. AUW, 20937, Życiorys Jerzego Zieleńskiego, [1969], bp.; E. Ciborowska, Leksykon..., s. 652.

23. Wspomnienie Krzysztofa Kąkolewskiego o Jerzym Zieleńskim, s. 1.

24. B. Zieleńska, Jerzy Zieleński, publicysta. 
Kąkolewski wspominał też, że Zieleński musiał wówczas przerwać studia. Pretekstem miało być to, że łączył je z pracą zawodową, co było źle widziane. „Sprawa Zieleńskiego wypłynęła pozornie dlatego, że pracuje, ale stało się to także okazją do «oceny postawy moralno-politycznej i sylwetki ideowej» - jak to się nazywało. Zwołano w tym celu specjalne zebranie otwarte Związku Młodzieży Polskiej, w które referent zaprezentował miażdżący, zapowiadający najgorsze bezlitosny portret Jurka. Obcość klasowa - był synem inż. arch., burżuazyjny styl życia - pracował, prowadził życie towarzyskie, niewłaściwy, wręcz oburzający styl nauki - opuszczał zajęcia, a miał dobre stopnie i wreszcie najgorsze, ponura przeszłość: był członkiem Armii Krajowej. Gdy przy bierności większości studentów, grupka kolegów broniła Jerzego argumentem, że walcząc w Powstaniu miał dopiero 16 lat, odpowiedziano, że dobrze że to zostało przypomniane, wskazuje to bowiem jak wcześnie Jerzy zdążył nasiąknąć wrogimi poglądami, jak dalece jest zdemoralizowany. Poddano pod głosowanie wniosek: usunąć z uczelni. Rodziło to dla Zieleńskiego nieobliczalne skutki, bo groziło wzięciem do wojska. Na jego małe dzieci mogła pracować żona. Wniosek przegłosowano i przedstawiono dziekanowi. Ale Jurek zawsze był uwielbiany, miał i ma - dokąd będziemy żyli - przyjaciół. Troje kolegów, w tym wymienię: nieżyjącą już Ziutę Zalewską i mieszkającą obecnie w Izraelu Elżbietę Górską, udało się do dziekana z interwencją, błaganiem, zaręczeniem, że biorą za Jerzego odpowiedzialność, obiecując, że go wychowają, zmienią, przetworzą. Nawet w tych nieopisanych czasach dało to skutek i Jurek został. Nie popełniwszy żadnej winy otrzymał naganę z ostrzeżeniem, która na długie lata zamknęła mu wstęp na studia magisterskie" ${ }^{\prime 25}$. W aktach uniwersyteckich Jerzego Zieleńskiego nie ma nic, co potwierdziłoby relację Kąkolewskiego, ale nie ma też niczego, co by podważałoby jej wiarygodność. Zieleński ukończył studia pierwszego stopnia w 1951 roku, ale studia magisterskie dużo później.

\section{Uwikłanie i wywikłanie}

Zanim doszło do opisywanych przez Krzysztofa Kąkolewskiego wydarzeń, Jerzym Zieleńskim zainteresowali się funkcjonariusze Urzędu Bezpieczeństwa. W 1951 roku dotarła do nich informacja o próbach konspiracyjnego zaangażowania Zieleńskiego w pierwszych latach po wojnie. Wykryto, że rozpowszechniał ulotki, zbierał amunicję oraz przechowywał pistolet ${ }^{26}$. Wówczas funkcjonariusze szantażem skłonili go do podjęcia z nimi współpracy, w wyniku czego w listopadzie 1951 roku został zarejestrowany jako informator ${ }^{27}$. Biorąc pod uwagę, że stało się to w szczytowym momencie stalinizmu, jest możliwe, że stosowano wobec niego typowe dla tego czasu ostre formy nacisku, wśród których groźby pozbawienia wolności mogły należeć do łagodniejszych. Sama świadomość metod, jakimi posługiwali się funkcjonariusze UB w tym czasie (z torturami na czele), mogła działać zastraszająco. Udało się go skłonić do sporządzenia i podpisania podyktowanego mu dokumentu następującej treści: "Zobowiązuję się do współpracy z organami Bezpieczeństwa Publicznego w celu wykrywania wszelkich wrogów Polski Ludowej. Zostałem poinformowany o konieczności zachowania tajemnicy państwowej i wiem, że za zdradę zostanę pociągnięty do surowej odpowiedzialności. Informacje będę podpisywał pseudonimem «Sergiusz»" 28 .

Historię relacji Jerzego Zieleńskiego z policją polityczną, która rozpoczęła się od powstania tego dokumentu, można odtworzyć przede wszystkim na podstawie dokumentów wytworzonych przez jej

25. Wspomnienie Krzysztofa Kąkolewskiego o Jerzym Zieleńskim, s. 2-3.

26. AIPN, 00191/157, Raport, 30 XI 1951, k. 18.

27. Ibidem, Kwestionariusz agenta informatora, 30 XI 1951, k. 16.

28. Ibidem, Zobowiązanie Jerzego Zieleńskiego, 30 XI 1951, k. 19. 
pracowników, jednak istotne uzupełnienia wnosi relacja Janiny Jankowskiej, której to bohater tego tekstu - najprawdopodobniej jako jedynej - opowiedział o całej sprawie; ich rozmowa na ten temat miała miejsce w 1977 roku $^{29}$.

Funkcjonariusze UB oczekiwali od Jerzego Zieleńskiego przekazywania informacji o tym, co działo się w redakcji "Sztandaru Młodych”, oraz o środowisku harcerzy związanych w czasie wojny z AK. Zieleński na pierwszym spotkaniu podał imiona i nazwiska swoich znajomych ze środowisk akowskich i harcerskich ${ }^{30}$. Na kolejnym spotkaniu powstał przywoływany już parokrotnie jego obszerny życiorys. Zawierał on szczegółowe informacje na temat jego konspiracyjnej działalności w czasie wojny i po jej zakończeniu. Zieleński, podając wówczas nazwiska osób, z którymi współpracował, podkreślał, że wierzy, że ich poglądy uległy zmianie. Można to odebrać jako próbę ich obrony. Jednocześnie jednak w sporządzonym bądź przez niego osobiście, bądź na podstawie jego słów dokumencie pojawiły się liczne informacje mogące sprowadzić na opisywane osoby duże kłopoty, łącznie $\mathrm{z}$ aresztowaniem. Zieleński przyznawał na przykład, że niedawno spotkał na szkoleniu wspomnianego już Andrzeja Skowrońskiego, związanego wcześniej z Narodową Organizacją Wojskową: „Przywitałem się z nim i z rozmowy dowiedziałem się, że pracuje w «Czytelniku», Kłoś natomiast pracuje w «Kurierze Codziennym». Poszedłem do redaktora naczelnego «Sztandaru Młodych», tow. Ludkiewicza i powiedziałem, co o nim wiem, oraz zapytałem do kogo mam pójść. Poradził mi on iść do personalnego «Czytelnika». Poszedłem i powiedziałem" ${ }^{\prime 31}$. Uzasadnieniem zachowania Zieleńskiego, o którym opowiedział, mógł być strach przed tym, że wypłyną informacje na temat jego powojennego konspiracyjnego epizodu. Jednocześnie jednak niewątpliwie przekazanie tych informacji mogło osobom, których one dotyczyły, bardzo zaszkodzić. Takie skutki mogło przynieść przekazanie tych informacji do kadr "Czytelnika”, a tym bardziej wspominanie o nich funkcjonariuszom UB.

Do życiorysu Jerzego Zieleńskiego dołączono kilkuzdaniowe charakterystyki osób, których dane podał on funkcjonariuszom. Wydaje się, że zwłaszcza w przypadku członków swojej rodziny i rodziny żony starał się minimalizować ewentualne negatywne konsekwencje. Tłumaczył, że o swojej rodzinie wie niewiele, bo poza ojcem nie ma z nikim kontaktu. Akcentował zmianę stosunku do ustroju niektórych osób. Sformułowania o takiej wymowie pojawiały się również w charakterystykach osób ze środowisk akowskich i harcerskich, ale były w nich również informacje mogące im bardzo zaszkodzić, dotyczące tego, co robili po wojnie (między innymi prób konspirowania lub złożenia propozycji ucieczki z kraju) ${ }^{32}$. Scharakteryzował też postawy kilku osób z redakcji „Sztandaru Młodych". Zieleński opisał funkcjonariuszom, jak z własnej inicjatywy złożył doniesienie do komórki PZPR na osobę napotkaną w czasie prac nad jednym tekstem: „Z moich spostrzeżeń w terenie byłem ostatnio w bazie rybackiej w Świnoujściu. Pisałem reportaż o brygadach młodzieżowych, o pracy organizacji ZMP. Zauważyłem, że tam jest brak czujności. Główny inżynier budowy, Rutyński, zawiózł mnie motocyklem na budowę, o której mówiłem, że to budowa wojskowa. Wcale tego nie pragnąłem oglądać i wróciłem uwagę na to sekretarzowi Podst[awowej] Org[anizacji] Partyjnej tow. Ludkiewiczowi redaktorowi naczelnemu «Sztandaru Młodych»"33. Janina Jankowska wspominała, że Jerzy Zieleński opowiadał jej o tej konkretnej sprawie. $\mathrm{Z}$ jego opowieści wynikało, że miał w związku z nią duże wyrzuty sumienia i spotkał się $\mathrm{z}$ tym inżynierem, żeby przeprosić go za to, że na niego doniós ${ }^{34}$.

\footnotetext{
29. J. Jankowska, Jerzy Zieleński (świadectwo), maszynopis w zbiorach autora.

30. AIPN, 00191/157, Znajomi inf. "Sergiusz" na kontakcie Sekcji III, XII 1951, k. 20-22.

31. Ibidem, Życiorys Jerzego Zieleńskiego, [1952], k. 28.

32. Ibidem, k. 28-36.

33. Ibidem, k. 31.

34. Relacja Janiny Jankowskiej (2020); J. Jankowska, Jerzy Zieleński (świadectwo).
} 
Trudno jednoznacznie stwierdzić, jakie dokładnie informacje Jerzy Zieleński przekazywał na kolejnych spotkaniach, gdyż nie zachowały się dotyczące ich dokumenty: ani składane pisemnie doniesienia, ani notatki sporządzane przez funkcjonariuszy. Z charakterystyki Zieleńskiego wynika, że informował o aktywności różnych osób. W ciągu kolejnych miesięcy spotykał się z funkcjonariuszami co najmniej kilkanaście razy, przekazując informacje zarówno ustnie, jak i pisemnie. Był przez nich oceniany jako osoba prawdomówna ${ }^{35}$. Spośród osób z otoczenia Zieleńskiego funkcjonariuszy UB najbardziej interesował Witold Piasecki jako potencjalny organizator "wrogich" działań. Zieleński w cytowanym życiorysie stwierdzał, że Piasecki "się chwieje i nie ma pewnego zdania”, ale jednocześnie informował o zaangażowaniu konspiracyjnym po wojnie jego i związanych z nim osób. Z charakterystyki Zieleńskiego sporządzonej przez funkcjonariuszy wynika, że to na podstawie informacji od "Sergiusza" założyli oni odrębną sprawę operacyjną dotyczącą Piaseckiego i że przekazywał on informacje na temat kolegi. Więcej na ten temat można się dowiedzieć z notatki służbowej sporządzonej przez funkcjonariuszy policji w 1980 roku na podstawie akt Witolda Piaseckiego w związku z ponownym zainteresowaniem Zieleńskim. W dokumencie znajdujemy następujący zapis: "Od dnia 30 XI 1951 r. do 20 XI 1953 r. kontrolę figuranta prowadzono głównie przy pomocy TW ps. «Sergiusz» - kolegi Piaseckiego z lat okupacji i Powstania Warszawskiego. W tym czasie «Sergiusz» przekazał 16 informacji charakteryzujących figuranta, jego działalność w czasie okupacji, poglądy polityczne po wyzwoleniu itp. Część informacji pisanych jest własnoręcznie przez TW. Z uwagi na to, że brat Piaseckiego pozostawał w Anglii, TW «Sergiusz» często $\mathrm{w}$ swych relacjach mówił o figurancie jako o przeciwniku politycznym, zwolenniku Zachodu a nie Wschodu. Sprawa prowadzona na Piaseckiego zakończyła się próbą pozyskania - nieudaną, po czym zakończono ją". Pod tekstem odnotowano jeszcze uwagę na temat Zieleńskiego: „W czasie rozpracowywania Piaseckiego «Sergiusz» pracował w «Sztandarze Młodych» - wykonywał więc zadania specjalnie mu zlecane, a nie wynikające np. ze wspólnego miejsca pracy"36. Trzeba pamiętać, że cytowany dokument oddaje perspektywę funkcjonariuszy UB, lecz jednocześnie podanych w nim informacji nie sposób lekceważyć. Z pewnością przekazanie tak dużej liczby informacji przez Zieleńskiego mogło Piaseckiemu bardzo mocno zaszkodzić.

Odrębną kwestią są motywacje bohatera tego tekstu. Mogły być one różne: od strachu poprzez ideowe zaangażowanie aż po wymierne korzyści. Wiadomo, że Zieleński odmawiał przyjmowania pieniędzy, tłumacząc, że współpracuje z UB "dla dobra Polski Ludowej", co można odczytać jako rzeczywisty wyraz poglądów albo jako ucieczkę od odgrywania roli płatnego informatora ${ }^{37}$. Sam Zieleński później mówił, że kierował się głównie strachem. Według Janiny Jankowskiej z prowadzonych z nim rozmów na ten temat wynikało, że takie miał wówczas poglądy i że podzielał pozytywną ocenę wprowadzonego w Polsce po wojnie ustroju. Jej zdaniem informacje o swoich znajomych z kręgów akowskich przekazywał dlatego, że uważał ich za ludzi, którzy błądzą i których postawę można "naprawić"38. Pisała o tym następująco: „Tak się złożyło, że byłam świadkiem tego ciężaru, który nosił Jerzy Zieleński, ciężaru, który był konsekwencją młodzieńczej wiary, że robi coś wymiernego dla odradzającej się po wojnie Polski. To był podpis i zgoda na współpracę podpisana w listopadzie 1951 r. W 1977 r. opowiedział mi o tym. Wyrzucił z siebie winę i ból, które go nie opuszczały aż do

35. AIPN, 00191/157, Charakterystyka informatora ps. "Sergiusz", 13 VIII 1953 r., k. 37.

36. Ibidem, Notatka służbowa spisana z akt archiwalnych Witolda Piaseckiego, 14 I 1980, k. 61.

37. Ibidem, Charakterystyka informatora ps. "Sergiusz", 13 VIII 1953 r., k. 37.

38. Relacja Janiny Jankowskiej (2020). 
tragicznej śmierci. "16-letni Powstaniec Warszawski poturbowany klęską, po wyzwoleniu miotał się między przyjaciółmi z konspiracji a otwierającymi się perspektywami ułożenia życia w nowej powojennej Polsce. Uwierzył w prosty opis świata i przyczyny klęski powstania. Rząd II RP uciekł drogą zaleszczykową z kraju. Z Londynu wysyłano młodych powstańców na śmierć. Elity zdradziły. Teoria walki klasowej porządkowała obraz. Wyzwoleńcza armia ze wschodu naprawia krzywdy, nowe prawo odbiera majątki obszarnikom, rozdaje ziemię chłopom. Sprawiedliwość. Trzeba odbudować Polskę na nowo. Uwierzyłem - mówił mi. I płakał. 0n, przyjaciel Adama Michnika, Jacka Kuronia, ważna postać opozycji demokratycznej miała ogromne poczucie winy. A przecież minęło już ponad 20 lat jak zerwał współpracę z SB. Potrzebował mi o tym powiedzieć. Zrozumiałam, że to, czego od niego nowa, komunistyczna Polska oczekiwała, zaczęło kłócić się z wartościami, które wyniósł z domu, z konspiracji. Czuł się jak w matni"39.

Trzeba pamięć, że obie relacje Jankowskiej (ustna i pisemna) zostały złożone po kilkudziesięciu latach od rozmów z Zieleńskim na temat jego współpracy z UB. Do tego jej relacja dotyczy nie samych faktów, ale właśnie motywacji, które Zieleński po latach mógł rekonstruować w zniekształcony sposób. Kolejne zniekształcenie tej historii mogło wynikać z czasu, jaki minął między rozmowami Zieleńskiego z Jankowską a złożeniem przez nią relacji. Wreszcie trzeba pamiętać, że w jej pamięci mogły się na siebie nakładać zapamiętane przez Zieleńskiego słowa o własnych motywach z jej interpretacjami jego postawy. Zapoznała się ona z materiałami archiwalnymi dotyczącymi tej sprawy. Jednocześnie jednak, biorąc pod uwagę to, co wiemy o postawie Zieleńskiego $\mathrm{w}$ tych latach oraz o przebiegu współpracy z UB, jej wersja dotycząca motywacji przyjaciela wydaje się przekonująca.
Współpraca Jerzego Zieleńskiego z UB z czasem przestała przynosić pożądane przez funkcjonariuszy efekty. W grudniu 1954 roku został on wyrejestrowany z sieci informatorów. Wśród powodów podano jego zły stan zdrowia oraz to, że jako członek ZMP nie miał kontaktu ze środowiskiem harcerskim, które interesowało funkcjonariuszy ${ }^{40}$. Mogło tak być rzeczywiście, jednak wydaje się, że gdyby chciał dalej współpracować, to mógłby kontakty interesujące UB odnawiać. Prawdopodobne wydają się również inne scenariusze. Zieleński mógł twierdzić, że nie ma takich kontaktów, próbując się wywikłać z niekomfortowej moralnie sytuacji, bądź też, co chyba najbardziej prawdopodobne, w tym celu przeciąć swoje dawne kontakty.

Obraz politycznej postawy Jerzego Zieleńskiego w latach stalinowskich jeszcze bardziej komplikuje wymowa złożonego na niego w marcu 1952 roku "doniesienia obywatelskiego". Informator o pseudonimie "Jacek" przekazał funkcjonariuszom jego obszerną charakterystykę. Stwierdza w niej między innymi: „Wydaje mi się bardzo "niepewnym gościem», a szczególnie wątpliwości mam co do najważniejszej strony - oblicza politycznego, które wydaje mi się «zamazane». Uważam go za dwulicowca. A oto przyczyny, które każą mi go tak surowo osądzać. Bardzo często w rozmowach o swej przeszłości opowiada o swych rozmaitych przygodach z życia m.in. o AK z miną niezupełnie szczerą. Mało - myślę, że mówi o tych różnych niezbyt jasnych i czystych sprawach zupełnie celowo". Według "Jacka" Zieleński miał stosować podczas rozmów przemyślaną strategię rzucania mimochodem informacji o swojej konspiracyjnej przeszłości. Miało to służyć obronie przed ewentualnymi zarzutami, że ukrywa te epizody swojego życia. „Jacek" podejrzewał, że poparcie Zieleńskiego dla ustroju jest pozorne. Podobnie oceniał jego żonę ${ }^{41}$. Nic nie wskazuje na to, by to doniesienie

39. J. Jankowska, Jerzy Zieleński (świadectwo).

40. AIPN, 00191/157, Raport o wyłączeniu z sieci informatora Zieleński Jerzy ps. "Sergiusz”, 24 XII 1954, k. 41

41. Ibidem, Wyciąg z doniesienia obywatelskiego z dnia 6 III 1952, k. 24. 
wpłynęło w jakikolwiek sposób na stosunek funkcjonariuszy UB do Zieleńskiego. Biorąc pod uwagę czas, w którym zostało ono złożone, nie można wykluczyć, że miało coś wspólnego z opisaną przez Kąkolewskiego historią zmuszenia Zieleńskiego do odejścia ze "Sztandaru Młodych" i jego problemami na uniwersytecie. Kimkolwiek był "Jacek", możliwe, że doniesienie złożył nie tylko funkcjonariuszom UB, ale również w strukturach ZMP, w miejscu pracy Zieleńskiego lub na uniwersytecie. Brak źródeł nie pozwala jednak stwierdzić na ten temat niczego na pewno. Trudno też powiedzieć, czy istniał jakiś związek między przebiegiem współpracy Zieleńskiego z UB i jego odejściem z uczelni i „Sztandaru Młodych".

Zupełnie inny niż w doniesieniu "Jacka” obraz postawy politycznej Zieleńskiego i jego poglądów w pierwszej połowie lat pięćdziesiątych wyłania się z jego charakterystyki sporządzonej w „Przyjacielu Żołnierza”. Jego praca w tej redakcji została oceniona pozytywnie. Zwrócono uwagę na jego wybuchowy charakter, nie wyrażono natomiast żadnych wątpliwości dotyczących jego politycznej postawy: „Jest członkiem ZMP, żywo interesuje się życiem politycznym kraju i świata, odważnie broni w dyskusjach swego stanowiska w poszczególnych sprawach. Jest szczery - i do obecnej rzeczywistości umotywowany pozytywnie"42. Wydaje się, że poglądy Zieleńskiego na rzeczywistość polityczną w pierwszej połowie lat pięćdziesiątych się nie zmieniały. Podobnie jak w przypadku wielu dziennikarzy duże znaczenie musiała mieć dla niego rozpoczynająca się w połowie dekady odwilż. Wówczas wielu ludzi z jego środowiska powoli zaczynało stawiać postulaty zmierzające $\mathrm{w}$ kierunku liberalizacji systemu. W marcu 1955 roku Jerzy Zieleński trafił do redakcji pisma „Dookoła Świata”, w którym zakotwiczył na wiele lat. Był to ukazujący się od stycznia 1954 roku atrakcyjnie ilustrowany magazyn, tworzony z myślą o młodzieży i publiku- jący wiele artykułów dotyczących zagranicy, co w tamtym czasie nie było typowe. Pisywał przede wszystkim reportaże.

Właśnie jako redaktor „Dookoła Świata” Jerzy Zieleński udał się do Poznania wkrótce po masowych protestach robotniczych, brutalnie spacyfikowanych przez władze w czerwcu 1956 roku. Z relacji Krzysztofa Kąkolewskiego, który pojechał tam wcześniej z kolegami ze "Sztandaru Młodych", wynika, że mieli problemy z ustaleniem jakichkolwiek szczegółów dotyczących tego, co się wydarzyŁo. Pomogło mu dopiero powołanie się na znajomość z kojarzonym w Poznaniu Zieleńskim: „Chcemy odtworzyć zasięg obecności tłumu i na tej podstawie obliczyć jego liczbę. Widzimy prywatny sklep. Jest otwarty. Pytamy właścicielkę, czy nie chciałaby opowiedzieć, cokolwiek zechce, o wczorajszym dniu; była tak blisko wydarzeń. Bada nasze legitymacje. Mit prasy już działa, ale pani chce się upewnić, czy jesteśmy dziennikarzami. - Zna pan dziennikarza Zieleńskiego? - Znam - odpowiadam - Ile on ma lat? - odpowiadam. Bada mnie, czy wiem, w jakiej redakcji pracuje, gdzie mieszka, jakie są jego stosunki rodzinne. Itd. Dzięki prawidłowym odpowiedziom otrzymujemy pierwszą relację o rozwoju wydarzeń pod Urzędem Bezpieczeństwa [...]. Stwierdziwszy, że Zieleński jest znany w Poznaniu, telefonujemy i wzywamy go na pomoc. Okazuje się, że Zieleński już się przygotowywał do wyjazdu". Bohater tego tekstu pojawił się w Poznaniu następnego dnia i zamieszkał wraz z kolegami ze "Sztandaru Młodych". "Nasz pokój, ogromny, na poddaszu, staje się czymś w rodzaju kwatery głównej. Natychmiast udajemy się do krewnych Zieleńskiego. Mówią, że na mieście są aresztowania, ale gotowi są udzielić nam wszelkiej pomocy i umożliwić kontakty. Piętnastoletni kuzyn Zieleńskiego zgłasza się na naszego przewodnika". Ostatecznie dzięki kontaktom Zieleńskiego grupie dziennikarzy udało się dotrzeć do ważnych świadków wydarzeń ${ }^{43}$. Cała relacja Kąkolewskiego

42. Ibidem, Notatka służbowa spisana z akt personalnych Jerzego Zieleńskiego, 27 XI 1979, k. 81.

43. K. Kąkolewski, Ile wiosen, tyle jesieni, [w:] Był taki dziennik "Sztandar Młodych”, red. W. Borsuk, Warszawa 2006, s. 151-152. Zob. też: Wspomnienie Krzysztofa Kąkolewskiego o Jerzym Zieleńskim, s. 3. 
jest bardzo barwna, widać w niej dziennikarskie pióro i literacką fantazję, ponadto zdaje się on idealizować postawę dziennikarzy. Niemniej wątek Zieleńskiego i jego kontaktów w Poznaniu wydaje się w pełni wiarygodny.

Poznański Czerwiec i późniejszy o kilka miesięcy Październik '56 z pewnością wpłynęły na zmianę poglądów politycznych Zieleńskiego. Wojciech Giełżyński wraz z Zieleńskim wiosną 1957 roku pojechali do Poznania i napisali reportaż 300 dni później. Pisali w nim między innymi: „Politycy niech z wypadków poznańskich i dalszego biegu wydarzeń w kraju wysuną wnioski co do metod zarządzania, zgodnych z wolą narodu". Wspominali, że w czerwcu 1956 wielu młodych robotników "dostało się do pomieszczeń starannie zamkniętych, inni zaś nie byli pewni dnia ani godziny, kiedy krążyły «czarne listy», kiedy «rady bogów», trzęsące fabrykami odgrywały się za krwawy czwartek". Podawali też wiele cytatów z bardzo krytycznych wobec władz wypowiedzi robotników ${ }^{44}$. Jesienią 1957 roku Zieleński wziął udział w protestach przeciwko likwidacji „Po Prostu”. Janina Jankowska zapamiętała jego anegdotyczną opowieść o tym, że w czasie ucieczki przed pacyfikującymi protest funkcjonariuszami ZOMO Zieleński zgubił but ${ }^{45}$.

Dobitnym wyrazem zmiany postawy Zieleńskiego wobec systemu była sytuacja z końca 1957 roku, kiedy to ponownie zainteresowali się nim funkcjonariusze policji politycznej ze względu na jego planowany zagraniczny wyjazd. Zachował on wobec nich zdecydowaną postawę. Jeden $\mathrm{z}$ funkcjonariuszy Służby Bezpieczeństwa na początku grudnia 1957 roku przyszedł do Zieleńskiego do domu i prawdopodobnie wymógł na nim spotkanie w kawiarni. Na początku pracownik policji politycznej poruszył temat Leszka Moczulskiego, który jeszcze niedawno wchodził w skład redakcji „Dookoła Świa- ta". Udostępniał on korespondentowi "Paris Match", Aleksandrowi Wołowskiemu, "Biuletyn Specjalny

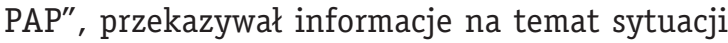
gospodarczej oraz wydarzeń w ZSRR, w związku z czym w październiku 1957 roku został aresztowany ${ }^{46}$. Zieleński miał wykazać bardzo sceptyczny stosunek do tej sprawy i twierdził, że Moczulski „był zupełnie niepoważnym człowiekiem i jeżeli zrobił jakieś głupstwo, za które został aresztowany to najprawdopodobniej przez głupotę i niepotrzebne gadulstwo". Słowa te mogą świadczyć o pobłażliwym stosunku Zieleńskiego do kolegi z redakcji, o próbie jego obrony lub o obu tych postawach jednocześnie.

Funkcjonariusza najbardziej interesowało to, czy Zieleński byłby gotów podjąć współpracę z SB. Rozmowa nie potoczyła się po jego myśli. W notatce służbowej relacjonował: „Następnie kierowałem dość długo rozmową w ten sposób, aby zorientować się, jak dziś «Sergiusz» zapatrywałby się na ewentualną współpracę z nami po linii walki z obcymi wywiadami. Widząc jego bardzo negatywny stosunek do poprzedniej współpracy z nami, uprzedziłem go, że dziś mówimy z nim na innej płaszczyźnie i w innych sprawach niż wówczas, gdyż «S[ergiusz]» cały czas podkreślał, że wówczas częściowo ze strachu, a także z ówczesnej atmosfery zgodził się robić «donosicielską robotę». W chwili obecnej ma różne zastrzeżenia wobec rozwoju naszej sytuacji politycznej, a także w ogóle nie chce się z niczym i nikim wiązać (jak powiedział: «chce mieć spokój») i z tych względów współpracować $\mathrm{z}$ nami nie chce. Była to konkluzja jego wypowiedzi, którą ubrał w bogatą otoczkę słowną. Reasumując, należy stwierdzić, że «Sergiusz» w chwili obecnej współpracować z nami w sposób zdecydowany nie chce"47.

Historia ta dobrze pokazuje, jak wydarzenia 1956 roku pomogły przełamać strach przed władzą. Ludzie nadal się bali, ale do niektórych zaczyna-

44. W. Giełżyński, Prywatna historia XX wieku, Warszawa 2005, s. 428-429.

45. Relacja Janiny Jankowskiej (2020).

46. Zob. K. Persak, Sprawa Henryka Hollanda, Warszawa 2006, s. 115-120.

47. AIPN, 00191/157, Notatka służbowa w sprawie spotkania z TW ps. "Sergiusz”, 6 XII 1957 r., k. 44. 
ło docierać, że nastała nowa sytuacja polityczna, w której funkcjonariusze organów bezpieczeństwa nie mogą zmusić obywateli do wszystkiego. Jednocześnie nie było jeszcze świadomości tego, że na nieformalne spotkanie $\mathrm{z}$ funkcjonariuszami SB nie trzeba przychodzić. Wiedza na ten temat w kręgach opozycyjnie nastawionej elity zaczynała się kształtować mniej więcej dwadzieścia lat później, po powstaniu zorganizowanej demokratycznej opozycji. Z relacji Janiny Jankowskiej wynika, że wyrzuty sumienia z powodu współpracy z UB towarzyszyły Zieleńskiemu przez całe życie ${ }^{48}$.

\section{Reporter i popularyzator nauki}

Przez kolejne lata Zieleński koncentrował się na pracy dziennikarskiej. Po przełomie 1956 roku rola prasy częściowo się zmieniła. Władze wciąż dążyły do tego, żeby praca dziennikarzy była podporządkowana ideologii i polityce ${ }^{49}$. Bardzo duża część dziennikarzy była dyspozycyjna wobec partii. Jednocześnie teksty ukazujące się w prasie, zwłaszcza jeśli nie dotyczyły polityki, nie musiały już dotykać kwestii ideologicznych. Zwłaszcza w reportażu opisywano wiele realnych społecznych problemów. Wielu dziennikarzy próbowało znaleźć swoją niszę, w której mogliby publikować wartościowe teksty niezależnie od polityki władz PRL, opisując to, co można było przedstawiać uczciwie ${ }^{50}$. Zieleński swoją niszę znalazł w popularyzacji nauki. Został nawet kierownikiem działu zajmującego się tą tematyką w "Dookoła Świata". Po latach nieco kokieteryjnie pisał: „W świątyni nauki byłem rzeczywiście od początku intruzem. Po prostu w wielonakładowym tygodniku, gdzie podówczas pracowałem, zawako- wało stanowisko kierownika popularnonaukowego, a w dziale krajowym, w którym dotychczas uprawiałem tzw. normalny reportaż, była nadmierna obsada etatowa. Zostałem zwyczajnie oddelegowany. $\mathrm{Na}$ moje zastrzeżenia, że brak mi przygotowania, że nie skończyłem nawet liceum mat.-fiz. ani żadnego wydziału uczelni, który by upoważniał itd., usłyszałem: Im się mniej o czymś wie, tym się lepiej pisze. Tkwiło w tym ziarno prawdy. Jeżeli nie lepiej, to łatwiej, człowiek nie jest skażony nadmierną wiedzą, która czasem, zwłaszcza skrupulantom uniemożliwia popularyzację" ${ }^{\prime \prime 1}$. W rzeczywistości nauka była jego prawdziwą pasją. Jego córka wspominała po latach: "Jak jedliśmy wspólnie obiad, tata na okrągło rozmawiał z moim bratem o nauce. Nawet mnie to denerwowało, że z nami mniej rozmawiał niż $z$ bratem" ${ }^{\prime 2}$.

Jerzy Zieleński jako dziennikarz z pokorą podchodził do wiedzy naukowej, swoimi tekstami starał się sprawiać, że stawała się ona przyswajalna dla zwykłych ludzi. Wizję swojej roli jako popularyzatora nauki po latach przedstawiał następująco: "Oto już lat przeszło dwadzieścia jak - samozwaniec, dyletant, człowiek zrządzeniem losu tylko rzucony na ocean nauki, niby rozbitek na tratwie - borykam się z dylematem śledzia, tak pięknie wyrażonym przez Mistrza Kotarbińskiego «Tu jasno, ale płytko - tam głębia, lecz ciemno». Francuzi na określenie popularyzacji używają ponoć słowa «wulgaryzacja»; podejrzewam, że większość moich rozmówców naukowych, z którymi w ciągu tego dwudziestolecia miałem kontakt, jeśli przez grzeczność i dobre wychowanie mi nawet tego nie mówiła, to właśnie tak sobie myślała o moich poczynaniach. Na usprawiedliwienie mam tylko to,

48. Relacja Janiny Jankowskiej (2020).

49. S. Ligarski, Żołnierze frontu ideologicznego, czyli władza wobec dziennikarzy w latach 1945-1989, [w:] Oblicza prasy Ziem Zachodnich w latach 1945-2012, red. A. Buck, P. Bartkowiak, D. Kotlarek, Zielona Góra 2012, s. 28; D. Wicenty, Załamanie na froncie ideologicznym. Stowarzyszenie Dziennikarzy Polskich od Sierpnia '80 do stanu wojennego, Gdańsk 2012, s. 15-19.

50. W. Suleja, Dziennikarz w Polsce Ludowej i PRL - kontestator i funkcjonariusz reżimu, [w:] Wolne media? Środowisko dziennikarskie w 1989 roku. Studia, red. P. Szulc, T. Wolsza, Szczecin-Warszawa 2010, s. 14.

51. J. Zieleński, Intruz w świątyni nauki, Warszawa 1980, s. 8.

52. Relacja Barbary Zieleńskiej (2020). 
że nie dla nich wybierałem się pisać o nauce; toteż jako ów śledź często bliżej byłem powierzchni niż przepastnych głębin. Choć nieustannie prześladował mnie ów dylemat, bo z drugiej strony, im częściej i bliżej obcowałem z nauką, tym bardziej rozumiałem złożoność tego, o czym mowa, czyli aby się już trzymać «wesołych smutków» 0jca Prakseologii, coraz częściej próbowałem nurkować głębiej. Wtedy jednak osadzał mnie na miejscu krzyk redaktorów: zbyt naukowe! Niezrozumiałe!"53. Zieleński starał się czynić zrozumiałymi problemy z wszystkich dziedzin nauki - od humanistycznych poprzez przyrodnicze aż po ścisłe.

Trzeba dodać, że nie ograniczał się do pisania o nauce. Wielokrotnie wyjeżdżał w podróże zagraniczne, podczas których zbierał materiały do reportaży. W latach 1956-1970 był w Finlandii, Francji, Mongolii, NRD, Cejlonie, Rumunii, ZSRR, Czechosłowacji, USA i Szwecji ${ }^{54}$. W 1961 roku ukazał się zbiór jego tekstów poświęconych Mongolii pod tytułem Sześciu mędrców z Bogatego Szczęś$\mathrm{cia}^{55}$, a dwa lata później książka Stan oblężenia w raju, zawierająca teksty na temat Cejlonu, za którą otrzymał nagrodę Klubu Publicystów Międzynarodowych Stowarzyszenia Dziennikarzy Polskich. W 1965 roku wraz z dziennikarzem Stefanem Bratkowskim wydał książkę $W$ tropikach inaczej na temat Polaków pracujących na eksportowych budowach $^{56}$. Za pracę dziennikarską Zieleński otrzymał w pierwszej połowie lat sześćdziesiątych nagrody Klubu Publicystów Międzynarodowych (1963) oraz Klubu Popularyzatorów Nauki i Techniki przy SDP (III nagroda, 1963). W 1964 roku został odznaczony Złotym Krzyżem Zasługi ${ }^{57}$.

Świadectwem atrakcyjności jego reportaży może być fragment wspomnienia Bratkowskiego: „W roku 1963 spotkałem na rogu Alei Jerozolimskich i Nowego Światu - Ryśka Kapuścińskiego, trzymał w dłoni książkę Jurka Zieleńskiego «Stan oblężenia w raju». Był już po tomie znakomitych reportaży krajowych «Busz po polsku», po pierwszych reportażach z Afryki, nie miał żadnych podstaw do kompleksów. Pokazując mi książkę Ziela (jak go nazywaliśmy), pokiwał głową - «Chciałbym kiedyś coś tak dobrego napisać». Roześmiałem się, bo wszyscy koledzy już wtedy w pełni doceniali talent Ryśka"58.

W 1965 roku równie pozytywną opinię wystawiły na temat Zieleńskiego kadry Zarządu Głównego RSW „Prasa”, w skład którego wchodziło „Dookoła Świata". Dotyczyła ona nie tylko jego pracy, ale też postawy politycznej: „mimo, że jest bezpartyjny, wykazuje duże zaangażowanie społeczne. Zarówno na terenie naszej redakcji, jak i poza nią jego postawa polityczna i moralna nie budzi ważnych wątpliwości. Jest wzorem obowiązkowości, solidarności dziennikarskiej i pracowitości. Należy do czołówki reporterów krajowych"59. Trzeba podkreślić, że ta opinia, po pierwsze, została napisana zgodnie z pewną konwencją, a po drugie, ten kto był jej autorem, nie musiał znać rzeczywistych poglądów Zieleńskiego. Z relacji członków rodziny wynika, że Zieleński, choć nie angażował się w opozycyjne inicjatywy (których zresztą było wówczas niewiele), negatywnie oceniał politykę władz. Dużym przeżyciem były dla niego wydarzenia Marca '68. Doświadczył brutalnej pacyfikacji wiecu studenckiego na uniwersytecie 8 marca 1968 roku. „Przyszedł do domu i opowiadał nam jak wyglądała owa demonstracja [...]. Był bardzo przejęty tym,

53. J. Zieleński, Intruz..., s. 7-8.

54. AIPN, 00191/157, Notatka służbowa, 28 XI 1979, k. 80.

55. J. Zieleński, Sześciu mędrców z Bogatego Szczęścia, Warszawa 1961.

56. S. Bratkowski, J. Zieleński, W tropikach inaczej, Warszawa 1965.

57. B. Zieleńska, Jerzy Zieleński, publicysta; E. Ciborowska, Leksykon..., s. 652-653.

58. S. Bratkowski, Zanim się wycofał, https://studioopinii.pl/archiwa/4396 (dostęp: 19.06.2020).

59. AIPN, 00191/157, Notatka służbowa spisana z akt personalnych Jerzego Zieleńskiego, 27 XI 1979, k. 82. 
co widział. Wielu jego przyjaciół pochodzenia żydowskiego musiało w tym czasie wyjechać z Polski. 0jciec bardzo to przeżył" - wspominała Barbara Zieleńska ${ }^{60}$.

Dwa lata wcześniej Jerzy Zieleński doświadczył kolejnej w swoim życiu tragedii. W 1966 roku po ciężkiej chorobie zmarła jego żona, Krystyna. Przeżył wówczas załamanie nerwowe, które doprowadziło do nieudanej próby samobójczej. Z czasem sytuacja się unormowała. Zieleński miał sporą rodzinę na utrzymaniu, w związku z czym bardzo dużo pracował. Dziećmi opiekowała się mieszkająca z Zieleńskimi od 1957 roku pomoc domowa, Zyta Gondek. Ona i jej córka stały się właściwie pełnoprawnymi członkami rodziny ${ }^{61}$. Zieleński z czasem ułożył sobie życie, wiążąc się z Elżbietą Gutkowską, prawniczką, pracującą jako prokurator (co warte podkreślenia, niezajmującą się sprawami politycznymi) ${ }^{62}$. Jeszcze przed śmiercią żony wrócił na studia na Uniwersytecie Warszawskim, w kolejnych latach dokończył je oraz napisał i obronił pracę magisterską Problem wychowania młodzieży do wynalazczości na przykładzie "Szkoły Wynalazców" miesięcznika "Młodych Technik"63.

Pierwsza połowa lat siedemdziesiątych była chyba najlepszym okresem w życiu zawodowym Jerzego Zieleńskiego. Jesienią 1970 roku przeszedł z redakcji „Dookoła Świata” do „Życia i Nowoczesności" - cotygodniowego dodatku do "Życia Warszawy", kierowanego przez Stefana Bratkowskiego. Główną tematyką tego dodatku były gospodarka, nauka i technika, ale pojawiały się w nim również tematy zahaczające o politykę. Kierowany przez Bratkowskiego zespół zachowywał niezależność w stosunku do "Życia Warszawy". Niektóre propagowane na łamach "Życia i Nowoczesności" poglądy (na przykład na temat efektywności zachodniej gospodarki) wywoływały bardzo negatywne reakcje władz. Zieleński pisywał felietony i należał do najbardziej poczytnych autorów. Bratkowski, szkicując genezę "Życia i Nowoczesności" oraz rolę, jaką odgrywał w tym piśmie Zieleński, po latach pisał: „W pierwszych latach sześćdziesiątych zawiązał się «stół» popularyzatorów nauki i techniki, ponieważ liczyliśmy, że rozwój sił wytwórczych stopniowo rozłoży paraliżujący wszystko system, a przy tym taka tematyka dziennikarstwa najmniej narażała się na ingerencje cenzury, bo cenzura się na tym nie znała. Obok reportażu i publicystyki Jurek zaczął uprawiać ten gatunek, pozwalający przemycać myśli zgoła niezależne - i bardzo długo miało potrwać, zanim ustrój zdołał się zorientować, że to działalność wrogich sił... Pisał Ziel oczywiście znakomicie. Kiedy pani Kazimiera Muszałówna, odchodząc na emeryturę, zaproponowała redaktorowi naczelnemu «Życia Warszawy», by mi oddał jej dział popularno-naukowy [...] ściągnąłem przede wszystkim Jurka. Powstał specjalny dodatek tygodniowy «Życie i Nowoczesność» [...]. Jurek okazał się, rzecz jasna, jednym z czołowych publicystów dodatku"64.

Jerzy Zieleński bardzo dobrze dogadywał się z kolegami z redakcji "Życia i Nowoczesności”, chociaż współpraca z nim nie zawsze była łatwa. "Nie był wulkanem energii, ale miał bezlitosne poczucie obowiązku. Przez długie okresy codziennie dochodził do kresu wydolności. Był miękki, opiekuńczy ale w kwestii zasad nieustępliwy aż do punktu zerwania. Znał ten punkt i np. w sprzeczkach usuwał się wcześniej" - wspominał po latach Jerzy Szperkowicz, również należący do zespołu „Życia i Nowoczesności" ${ }^{65}$. Na nieustępliwość Zieleńskiego w sprawach merytorycznych zwracał uwagę Bratkowski: „Nie uginał się pod żadnymi naciskami. Nie uznawał kompromisu w żadnych sprawach merytorycznych.

60. List od Barbary Zieleńskiej do Jana Olaszka (2020).

61. Relacja Barbary Zieleńskiej (2019).

62. Relacje Barbary Zieleńskiej (2019) i Bogumiły Zieleńskiej (2020).

63. AUW, 20937, Dyplom ukończenia studiów wyższych Jerzego Zieleńskiego, 18 X 1969, bp.

64. S. Bratkowski, Zanim się wycofał.

65. J. Szperkowicz, W rocznicę Ziela, "Odra", styczeń 1985, s. 54. 
Jedyne co można mu było zmienić $\mathrm{w}$ tekście, to ewentualnie jakieś literówki (choć zgadzał się na redagowanie tekstów przez najbliższego kolegę). W «Życiu i Nowoczesności» w latach 1970-1973 odegrał rolę czołowego publicysty. Zdawaliśmy sobie sprawę z ograniczeń narzuconych przez reżim, ale zasadą było: nie poddawać się i zmieniać rzeczywistość, jak dalece się da - w stronę demokracji i wolności. I odebrał największą nagrodę, jakiej mógł mu udzielić miniony reżim - rozpędzenie zespołu i pozbawienie pracy" ${ }^{\prime \prime 6}$.

Wspomniana linia "Życia i Nowoczesności" doprowadziła do usunięcia redaktora naczelnego oraz trzonu zespołu jesienią 1973 roku. Bratkowski po latach tłumaczył: „Pokazywaliśmy jak mogłoby być, jak co mądrego i dobrego robią gdzie indziej po świecie, organizowaliśmy dyskusje uczonych i różne niewinne akcje, jak mobilizacja producentów... pieluch i wszystkiego, co potrzebne do pielęgnacji niemowląt, pod hasłem «niemowlę też człowiek». Potem się okazywało, że cokolwiek proponowaliśmy, od samorządu lokalnego po samodzielność przedsiębiorstw, cokolwiek ukazywaliśmy do naśladowania z zagranicy, było buntem, nieustannym wywrotowym podszczuwaniem do buntu. Kiedy nas ostatecznie rozpędzono jesienią 1973 r., sekator prasy, nieznoszący naszego dodatku sekretarz KC, Jerzy $€$ [ukaszewicz], wydał zakaz zatrudnienia Jurka i mnie w prasie" ${ }^{67}$. Zieleński odszedł z "Życia i Nowoczesności" w lutym 1974 roku.

Jeśli rzeczywiście wspomniany przez Bratkowskiego zakaz został wydany, to w odniesieniu do Zieleńskiego miał on zastosowanie krótko, bo szybko znalazł on przystań w tygodniku "Literatura". Na czele redakcji stał formalnie Jerzy Putrament, jeden z tych znanych w PRL pisarzy, których kariera literacka opierała się przede wszyst- kim na karierze w PZPR. Faktycznie czasopismem kierował Gustaw Gottesman, który wcześniej był redaktorem zamkniętego w 1963 roku "Przeglądu Kulturalnego"68. "Literatura" dość często drukowała teksty nie w pełni zgodne z polityką władzy i niekoniecznie pisane przez autorów dobrze przez nią widzianych. Wkrótce okazało się jednak, że parasol rozłożony nad pismem przez Putramenta był dziurawy. W kwietniu 1975 roku usunięto z zespołu Gottesmana ${ }^{69}$. Wówczas z "Literatury” odszedł również Zieleński.

Trafił do redakcji "Problemów”, z którymi współpracował już wcześniej. Profil tego pisma bardziej pasował do jego zainteresowań. Był to miesięcznik zajmujący się popularyzacją nauki. Zieleński został w nim kierownikiem działu nauk medycznych i technicznych. Równolegle w końcówce lat siedemdziesiątych i na początku lat osiemdziesiątych publikował felietony w "Wiedzy i Życiu" w cyklu zatytułowanym Listy do samego siebie. W lekki i przystępny sposób pisywał w nim o sprawach nauki. Swoje poglądy prezentował w formie listów skierowanych do siebie, których autor na ogół z nim się nie zgadzał.

W pierwszej połowie lat siedemdziesiątych ukazało się kilka książek Zieleńskiego. W roku 1970 wyszła książka Technika i ja pod jego redakcją, zawierająca teksty nadesłane w odpowiedzi na ankiety czytelnicze $^{70}$. Rok później światło dzienne ujrzała książka Dajcie szansę ziemi. Zieleński wybrał do niej teksty dotykające problematyki ekologicznej, opublikowane przez różnych autorów w czasopismach. Jest to pozycja szczególnie ciekawa, ponieważ tematyka ta była wówczas w Polsce nowością ${ }^{71}$. Wśród autorów obok specjalistów pojawili się także bardzo znani wówczas dziennikarze: Andrzej Bober, Kazimierz Dziewanowski, Daniel Passent,

66. S. Bratkowski, Sens przyzwoitości, „Rzeczpospolita”, 24 VI 2002, s. 2.

67. Idem, Zanim się wycofat.

68. J. Tomkowski, Lata 1961-1970, [w:] Czasopisma społeczno-kulturalne w PRL, red. U. Jakubowska, Warszawa 2011 , s. 172.

69. U. Jakubowska, Lata 1971-1980, [w:] ibidem, s. 300.

70. Technika i ja, wybór i oprac. J. Zieleński, Warszawa 1970

71. Dajcie szansę ziemi, wybór J. Zieleński, Warszawa 1971. 
Marek Skwarnicki, Tadeusz Strumff, Jerzy Urban i Maciej Wierzyński. Zawartość książki Zieleński charakteryzował następująco: „Wspólny mianownik przedstawionego Czytelnikowi zbioru [...] to walka o ochronę biologicznego środowiska ludzkiego, walka o wodę i powietrze, walka $\mathrm{z}$ hałasem i nadmierną chemizacją otoczenia [...]. Książka zawiera także teksty obowiązujących w Polsce podstawowych aktów ustawodawczych o ochronie przyrody i środowiska ludzkiego. Poglądy tu wyrażone nie są jednostronne, dopuszczono repliki, polemiki i głosy przekorne, aby Czytelnik uzyskał możliwie szeroki pogląd na zagadnienie; aczkolwiek inspiratorzy tej książki nie kryją, że uważają alarm wszczęty w obronie środowiska biologicznego za słuszny i uzasadniony, podpisując się oburącz pod apelem sekretarza generalnego ONZ [Sithu] U Thanta"72. Zieleński nawiązywał do raportu Człowiek $i$ środowisko, przygotowanego na polecenie Zgromadzenia Ogólnego ONZ przez birmańskiego polityka w 1969 roku.

W tej książce Zieleński zamieścił również swój artykuł, pierwotnie opublikowany na początku 1970 roku w warszawskiej „Kulturze” pod tytułem Liczenie motyli albo: o Ojcowie bez sentymentalizmu. Zaczynał przekornie: „Obiecuję, że nie będę raz jeszcze straszył rakiem płuc, nie będę cytował apelu U Thanta, nie będę obliczał zawartości DDT w ciele pingwinów ani ryb śniętych w zatrutych rzekach. Przyrzekam także, że nie napiszę sprawozdania z -nastej (-dziesiątej już) konferencji w sprawie ratowania Parku Narodowego w 0jcowie, która się niedawno odbyła w Krakowie z inicjatywy Zarządu Głównego i Komisji Ochrony Przyrody PTTK. Chciałbym najwyżej przytoczyć parę argumentów przemawiających za tym, żebyśmy nie rozdeptali do końca tego, co z parku pozostało, bo może jednak nie warto, bo może jednak szkoda". Zieleński podkreślał, że zabytki krajobrazowe powinny być tak samo chronione jak zabytki architektoniczne i eksponaty w muzeach; przekonywał o niepowtarzalnym klimacie ojcow- skiego parku, przywoływał też nazwiska twórców, którzy w nim regularnie bywali właśnie ze względu na tamtejszą przyrodę.

Widać było, że temat ten jest dla niego osobiście ważny. Obrazowo i w emocjonalny sposób pisał o dewastacji, jakiej dokonuje masowy ruch turystyczny, nieregulowany żadnymi obostrzeniami: „W każdym muzeum na świecie obowiązują określone reguły; w 0jcowie są one łamane i deptane; nie tylko w sensie metaforycznym. Pewnej niedzieli między Piaskową Skałą a Murownią naliczono w ciągu jednej godziny 300 autokarów po circa 50 ludzi każdy, 250 tysięcy turystów rocznie - ćwierć miliona - przewala się jak tatarska horda przez 0jców. Nie wiadomo do dziś wprawdzie, ile się mieści diabłów na główce od szpilki, stwierdzono natomiast, że na masce jednego samochodu osobowego zmieściły się 172 motyle martwe; wśród nich były na pewno i egzemplarze stanowiące unikat przyrodniczy rezerwatu. Wszystko wali akurat w samo serce, w dolinę Prądnika, runo zdeptane na placek, erozja brzegów, zrzucanie głazów, które tu narosły jeszcze w epoce jurajskiej. Klaksony i tranzystory płoszą rzadkie ptactwo i zwierzynę. Żółta zastoina spalin na wysokość 4 metrów utrzymuje się jeszcze długo po niedzieli w wąwozie, na którym na domiar złego występuje zjawisko inwersji, co sprzyja gromadzeniu się wszelakich zanieczyszczeń [...]. Mleczarnia w Skale, ujęcie wód ze źródeł rzeki dla wsi Słoszowa, choć przecie były inne koncepcje rozwiązań, ścieki z domów mieszkalnych i placówek usługowych zmieniły Prądnik w cuchnący rynsztok. Działalność usługowa w 0jcowskim Parku Narodowym to rozdział osobny: przypomina owych kupczących w świątyni, Chrystusa tylko zabrakło, żeby ich przegnał. Dwie restauracje (z wyszynkiem), parking pod Zamkiem, bazy noclegowe, kioski gastronomiczne i z pamiątkami, również koszmarnymi jak gdzie indziej, dopełniają pejzażu doliny ozdobionego po każdej niedzieli przysłowiowymi już skorupami po jajach na twardo i butelkami w całości

72. Ibidem, tekst Jerzego Zieleńskiego na skrzydełku okładki książki. 
oraz szkłem tłuczonym". Przedstawiając wiele argumentów wskazujących na znaczenie 0jcowskiego Parku Narodowego, apelował o wprowadzenie opłat za wstęp i czasowe zamknięcie parku ${ }^{73}$. Zieleński nie chciał schlebiać czytelnikom, ale przekonywać do spraw, które uważał za ważne.

W 1973 roku ukazał się zbiór jego felietonów na temat nauki, napisanych w poprzedniej dekadzie w "Dookoła Świata”, pod wymownym tytułem $A$ jednak się kręci ${ }^{74}$, a rok później książka Demon przychodzi we środy, zawierająca jego reportaże z różnych krajów z lat 1956-1966 ${ }^{75}$. Na jego dorobek składają się również teksty do filmów popularnonaukowych Wytwórni Filmów Dokumentalnych w Łodzi i nowela, na podstawie której powstał scenariusz do serialu telewizyjnego Najdłuższa wojna nowoczesnej Europy w reżyserii Jerzego Sztwiertni ${ }^{76}$. Ukazano w nim historię walki z germanizacją w Wielkopolsce. Historia tego regionu była jego pasją. Wyrażała się w niej jego postawa życiowa. "Ojciec był z duszy pozytywistą i zwolennikiem mądrej gospodarki, a nie romantycznych szaleństw. Wkładał nam to do głowy od dziecka" - wspominała Barbara Zieleńska ${ }^{77}$.

Na ukształtowanie takiej postawy życiowej miały wpływ jego doświadczenia wojenne. Zieleński niechętnie do nich wracał ${ }^{78}$. Stefan Bratkowski wspominał: „Nie wiem, na której barykadzie spędził Powstanie, spotkałem jego z niej kolegów, twardo podtrzymywał odwagę pozostałych, nawet starszych od siebie, ale nie lubił mówić o sobie, panował zresztą snobizm, by nie mówić o sobie, $i$ to nie tylko dlatego, że przed rokiem 1956 byłoby to ryzykowne. Kiedy ktoś zaczynał temat, mówiło się w powietrze, że «coraz więcej mamy powstańców i gdybyśmy ich wtedy tylu mieli...»"79. Jednocześnie akowska przeszłość dla Zieleńskiego była niewątpliwie ważna. W 1957 roku za udział w powstaniu warszawskim otrzymał Krzyż Walecznych. Powstanie uważał przede wszystkim za tragedię. Z dziećmi odwiedzał groby powstańców, co roku odwiedzał też kwaterę batalionu "Gustaw", gdzie spotykał się z kolegami z czasów powstańczych. Jego córka wspominała, jak spotkał się ze swoim dowódcą: „Nagle tata się zrobił inny. Odnosił się do niego $\mathrm{z}$ wielkim szacunkiem; widać było, że był bardzo przejęty". Jednocześnie wspominała, że ojciec burzył jej romantyczne spojrzenie na powstanie: „Zawsze mówił, że to było niepotrzebne i szkoda było tych ludzi"80. W latach siedemdziesiątych pisywał wiersze nawiązujące do tej części swojej przeszłości, nie próbował ich jednak publikować - deponował je u Janiny Jankowskiej (obecnie w posiadaniu rodziny). W wierszu Bataliony z maja 1976 roku pisał:

Bataliony wyszły na ulice

Bataliony otrzymały kwatery

Bataliony otrzymały numery

Bataliony stoją w poprzek drogi

Bataliony legły w poprzek drogi

Bataliony otrzymały kwatery

Bataliony otrzymały numery

Bataliony leżą wzdłuż alei

Bataliony leżą i czuwają

Nasłuchują, czy im zdać nie dają

Żeby znowu otrzymać kwatery

Żeby znowu otrzymać numery -

- drzewa szumią śpijcie nikt nie woła ${ }^{81}$

73. J. Zieleński, Liczenie motyli albo: o Ojcowie bez sentymentalizmu, [w:] ibidem, s. 151-159.

74. Idem, A jednak się kręci, Warszawa 1973.

75. Idem, Demon przychodzi we środy, Warszawa 1974.

76. Informacje drodze zawodowej Zieleńskiego i jego dorobku na podstawie: B. Zieleńska, Jerzy Zieleński, publicysta; E. Ciborowska, Leksykon..., s. 652-653; AIPN, 00191/157, Notatka służbowa spisana z akt personalnych Jerzego Zieleńskiego, 27 XI 1979, k. 81.

77. Relacja Barbary Zieleńskiej (2019).

78. Relacje Barbary Zieleńskiej (2019), Bogumiły Zieleńskiej (2020) i Janiny Jankowskiej (2020).

79. S. Bratkowski, Sens przyzwoitości, s. 2.

80. Relacja Barbary Zieleńskiej (2019).

81. J. Zieleński, Wiersze, "Odra", styczeń 1985, nr 280, s. 55. 
Ważnym elementem życia dziennikarza w czasach PRL była nie tylko sama praca, ale też funkcjonowanie w środowisku zawodowo-towarzyskim. Zieleński miał wielu przyjaciół i znajomych. Spośród dziennikarzy najbliżej był związany ze Stefanem Bratkowskim, Kazimierzem Dziewanowskim, Krzysztofem Kąkolewskim, Wojciechem Adamieckim, Magdaleną Bajer i Janiną Jankowską

\section{Dziennikarz w opozycji}

W połowie lat siedemdziesiątych Zieleński miał wiele kontaktów z ludźmi, który zaangażowali się w działania opozycyjne. Nie był sygnatariuszem żadnego $\mathrm{z}$ listów protestacyjnych w prawie poprawek do Konstytucji PRL, jednak - według doniesienia złożonego przez kontakt operacyjny SB ps. "Jacek” - na spotkaniu w Stowarzyszeniu Dziennikarzy Polskich z Jerzym Bafią (prezesem Sądu Najwyższego) miał należeć do osób zabierających głos w sposób najbardziej krytyczny wobec proponowanych zmian ${ }^{83}$. Zieleński bezpośrednio nie uczestniczył w akcji pomocy dla osób represjonowanych po Czerwcu '76, ale wraz z Janiną Jankowską, którą wciągnął do działalności opozycyjnej84 (później niektóre wydawane w podziemiu taśmy podpisywała imieniem i nazwiskiem jego matki - „Wanda Szaad"). Współpracował wówczas z Piotrem Naimskim. Oboje najczęściej spotykali się z nim w okolicach Dworca Centralnego, następnie jeździli po mieście małym fiatem Jankowskiej, załatwiając różne sprawy związane $\mathrm{z}$ działalnością opozycyjną ${ }^{85}$. Jedno $z$ ich spotkań odnotowała $\mathrm{SB}^{86}$. Jankowska wspominała, że razem szukali miejsc do druku korowskich publikacji oraz że Zieleński w kilku sytuacjach, gdy SB wzywała ją na przesłuchania, tłumaczył, jakie ma prawa i co powinna zrobić87. Pisała o tym następująco: „Wtedy właśnie uczył mnie jak rozmawiać z SB-kami w czasie przesłuchań. Paradoksalnie doświadczenia okresu jego współpracy z SB, służyły teraz opozycji demokratycznej. Znał mechanizmy nacisków, jakie służby stosowały. Przestrzegał nas przed nimi. Osobiście jemu zawdzięczam, że nie «pękłam» w czasie przesłuchań, rewizji a później w czasie internowania i w więzieniu na Rakowieckiej"88.

Rozwijającą się w Polsce od jesieni 1976 roku prasę niezależną tworzyli przede wszystkim ludzie niemający właściwie żadnych doświadczeń dziennikarskich. Zbierania informacji, ich weryfikowania, pisania i redagowania tekstów uczyli się w praktyce. Dziennikarzy ze stażem w oficjalnej prasie gotowych zaangażować się po stronie opozycji było dosłownie kilku i jednym z nich był, jak już wspomniałem, Jerzy Zieleński. Dla pism drugiego obiegu drukowanie dłuższych tekstów osoby o takim doświadczeniu jak Zieleński było bardzo ważne. Chodziło o to, żeby pisma te nie były tylko "stusznymi" biuletynami, ale zawierały również teksty dobrze napisane i po prostu ciekawe. Dobre dziennikarskie pióra dla drugoobiegowych redakcji stanowiły więc prawdziwy skarb. Pośród osób poszukujących kontaktów w środowiskach dziennikarskich był jeden z liderów środowiska korowskiego, Adam Michnik, któremu polecono Zieleńskiego. Wiadomo to, bo podobnie jak wielu opozycjonistów, Zieleński został poddany drobiazgowej inwigilacji, której bardzo wiele efektów można znaleźć w dotyczących go

82. Relacje Barbary Zieleńskiej (2019) i Janiny Jankowskiej (2020).

83. AIPN, 00191/157, Notatka służbowa, 3030 VI 1978, k. 90.

84. J. Jankowska, Jerzy Zieleński (świadectwo).

85. Relacja Janiny Jankowskiej (2020).

86. AIPN, 00191/157, Pismo Zastępcy Naczelnika Wydziału IX Departamentu III MSW do Naczelnika Wydziału III-2 KSM0, 5 IV 1979, k. 114; ibidem, Pismo Zastępcy Naczelnika Wydziału III-2 KSM0 do Zastępcy Naczelnika Wydziału IX Departamentu III MSW, k. 115.

87. Relacja Janiny Jankowskiej (2020).

88. J. Jankowska, Jerzy Zieleński (świadectwo). 
materiałach. Są tam notatki z podsłuchu jego rozmów telefonicznych, notatki i zdjęcia z obserwacji ulicznej oraz kopie jego listów przeglądanych przez funkcjonariuszy. Mimo że policja polityczna wielokrotnie podsłuchiwała, jak Michnik i Zieleński umawiają się na spotkania, to jedynie dwa razy udało jej się odnotować fakt samego spotkania ${ }^{89}$. SB podejrzewała, że Zieleński publikuje pod pseudonimem w prasie drugiego obiegu ${ }^{90}$, nie wiedziała jednak, w których dokładnie pismach i pod jakim pseudonimem. Tymczasem Zieleński współpracował $\mathrm{z}$ trzema tytułami niezależnej prasy, wydawanymi przez środowisko Komitetu Samoobrony Społecznej „KOR”: „Biuletynem Informacyjnym”, „Robotnikiem" i "Zapisem".

Współpraca z „Zapisem” zaczęła się prawdopodobnie najwcześniej, ale miała raczej incydentalny charakter, bo ograniczała się do zamieszczenia jednego tekstu. W styczniu 1978 roku Zieleński opublikował pod pseudonimem „Władysław Jasiński" artykuł 0 głupim dowcipie, który zrobiono Ludwikowi Waryńskiemu. Tekst składał się z kilku komentarzy do różnych sytuacji z peerelowskiej rzeczywistości, świadczących o wewnętrznej sprzeczności gospodarczej polityki władz. Na wstępie odnotowywał pojawienie się wizerunku słynnego rewolucjonisty na banknocie stuzłotowym: „Twarz Ludwika Waryńskiego symbolizująca pieniądz, nie wyczuwacie sprzeczności? Pieniądz miał być obalony po zwycięstwie rewolucji od zaraz. Ze złota, odgrażano się, będziemy budować wychodki. Dziś nam już wiadomo, że Waryński i jemu podobni to byli naiwni utopiści. Po chwyceniu władzy przez rewolucję przywódcy jej zrozumieli szybko, że bez pieniądza się nie obejdzie. Przejściowo, oczywiście. Jego rola społeczna będzie malała stopniowo, aż w komunizmie stanie się on nieprzydatny. Obecnie wedle urzędowych oświadczeń znajdujemy się na etapie rozwiniętego społeczeństwa socjalistycznego. Należy to chyba zrozumieć jako dalszy krok w stronę komunizmu. Tymczasem nie dostrzegamy żadnych oznak zanikania roli pieniądza. Nie tylko funkcjonuje on w naszym społeczeństwie, ale teraz wydaje się wręcz nabierać znaczenia. Wzrost wpływów pieniądza jako wielofunkcyjnej, złożonej instytucji, jest zgodny z intencją partii i rządu. Przywódcy mówią o rachunku ekonomicznym nieomal jak o jednym $\mathrm{z}$ dogmatów leninizmu, oficjalni ekonomiści snują marzenia o przywróceniu swobodnej gry mechanizmów rynkowych jako panaceum na chaos gospodarczy. Październik miesiącem oszczędzania. Wyrafinowane odmiany książeczek PKO z oprocentowaniem i bez, docelowe i w ogóle. Pewexy, o których za chwilę. Odkładanie na samochód. Nigdy w naszym społeczeństwie nie panował taki kult cnót mieszczańskich jak na etapie rozwiniętego socjalizmu". Zieleński nie był przeciwnikiem liberalizacji gospodarki, jednak zwracał uwagę, że w systemie gospodarki centralnie zarządzanej i tak musi ona "funkcjonować jak źle skonstruowana maszyna, rodzić osobliwości lub nawet dziwolągi. Jest to cielę z dwiema lub trzema głowami".

Zieleński przywoływał dwa teksty przeczytane w tym samym numerze "Trybuny Ludu" z lata 1977 roku. W jednym z nich Jerzy Putrament wypowiadał się o wyższości socjalizmu nad kapitalizmem, który miał oddawać wybór między "być" i "mieć". Zestawiał go z tekstem o motoryzacji, w którym chwalono wprowadzenie wyższych cen za przyspieszony zakup samochodu. Zieleński wskazywał, że ludzie mniej zamożni muszą czekać na samochód bardzo długo, odkładając skrupulatnie swoje pieniądze na specjalne książeczki, lecz wyprzedzają ich w kolejce ci, którzy po prostu zapłacą więcej. „W istocie mamy do czynienia z genialną innowacją ekonomiczną - komentował Zieleński. - Chcąc zlikwidować czarny rynek, państwo przejmuje jego funkcje. Tego jeszcze nie było. Temida jest nie tylko ślepa, ale widzi na jedno oko: karze drobnych cinkciarzy, nie dostrzega zaś supercinkciarza, jakim

89. Ibidem, Informacja dot. Jerzego Zieleńskiego, 4 IV 1979, k. 11.

90. Ibidem, Notatka służbowa dotycząca Jerzego Zieleńskiego, 5 XII 1979, k. 75. 
stało się państwo". W podobnym duchu Zieleński komentował funkcjonowanie Pewexów, wychodząc od przeczytanego w jednej z gazet hasła "Zwiedzaj świat - kupuj w Pewexie", które interpretował jako zachętę do uprawiania "turystyki handlowej”. Pisał o demoralizacji społecznej, powodowanej przez robienie dużych pieniędzy dzięki powiązaniom z władzami PRL. Wskazywał też na produkcję krótkich serii ekskluzywnych urządzeń, zamiast zwiększania standardu urządzeń dostępnych masowo. Zieleński kończył tekst ostrymi słowami: „Z tych rozważań można by wnioskować, że chodzi o wąską stosunkowo grupę ludzi. Otóż nie. Każda mafia dzieli się na «ojców chrzestnych» i drobnych klientów. W tym systemie, gdzie wszyscy narzekają, prosperuje co najmniej milionowa armia ludzi, którzy się urządzili, znaleźli sobie nisze ekologiczne, gdzie im się bytuje jako tako, chwalić boga, ciotki działaczy i sutenerzy, skorumpowani milicjanci i cinkciarze, zasłużeni renciści i osoby $\mathrm{z}$ chodami bądź $\mathrm{w}$ aparacie władzy, bądź handlu, luksusowe kurwy i karierowicze $\mathrm{z}$ organizacji młodzieżowych... Niech nikt nie liczy na to, że większość tych ludzi jest zainteresowana w autentycznych zmianach w Polsce. Choćby nie wiem, jak narzekali. Byt bowiem określa świadomość. Biedny Waryński na tej stuzłotówce..." ${ }^{11}$.

Temat korumpowania ludzi w PRL przywilejami stanowił jeden $\mathrm{z}$ charakterystycznych elementów drugoobiegowego pisarstwa Zieleńskiego, powracający w kolejnych jego tekstach. W jednym z numerów „Biuletynu Informacyjnego”, z którym był on najbardziej związany, przedstawił cztery sylwetki: lekarza psychiatry Barbary Walczak, prorektora Uniwersytetu Wrocławskiego Karola Fiedora, publicysty Wiesława Górnickiego i prezesa Polskiej Akademii Nauk Witolda Nowackiego. Pisał o nich: "Cztery osoby, które pozornie nie mają nic wspólnego [...]. Co tych ludzi łączy? Zostali wymienieni w jednym numerze «Komunikatu KSS KOR» $\mathrm{i}$ «Biuletynu Informacyjnego» jako osoby, które w pełnieniu swej funkcji lub wykonywaniu rzemiosła czy też zawodu przekroczyły granice gorliwości urzędniczej". Przyczynę tych postaw widział właśnie w przywilejach dostępnych w PRL jedynie wąskiej grupie obywateli ${ }^{92}$.

W „Biuletynie Informacyjnym” Zieleński zaczął publikować w 1978 roku $^{93}$. Jeden z jego najważniejszych tekstów, reportaż Zwyczajni ludzie, dotyczył działaczy Wolnych Związków Zawodowych Wybrzeża. Tekst przedstawiał codzienność gdańskich opozycjonistów, opisywał stosowane wobec nich represje, działalność samokształceniową i kolportaż korowskiego „Robotnika”"94. Zieleński zgodnie $\mathrm{z}$ reporterskim rzemiosłem opisywał okoliczności rozmów, przytaczał wypowiedzi bohaterów, starał się zachować rzetelność i nie nadawać opisywanej inicjatywie większego zasięgu, niż miała w rzeczywistości: "Czas był gorący pomimo zimy i mrozu, bo rozpoczęto właśnie akcję rozlepiania zawiadomień o uroczystości pod bramą Stoczni i bezpieka zaczęła deptać związkowcom po piętach. «Grudzień to na Wybrzeżu niebezpieczna pora» - można by sparafrazować poetę. Mieszkanie, w którym spotkałem przedstawicieli WZZ, było prawdopodobnie na podsłuchu, wobec tego udaliśmy się gdzie indziej. - Zaktywizowali się od września - oświadczyli moi rozmówcy - rewizje, przesłuchania, próby represji i prowokacji. Musiały przyjść jakieś dyrektywy z góry, żeby się za nas ostrzej wziąć. Uznali nas widocznie za niebezpiecznych. Chociaż jest nas zaledwie parę osób występujących jawnie, mamy tu zaplecze: na Wybrzeżu

91. W. Jasiński [J. Zieleński], o głupim dowcipie, który zrobiono Ludwikowi Waryńskiemu, „Zapis” 1978, nr 5, s. 96-100.

92. Idem, Rejtanowie własnych przywilejów, "Biuletyn Informacyjny” VII-VIII 1979, nr 31/32, s. 71-74.

93. A. Friszke, Opozycja polityczna w PRL 1945--1980, Londyn 1994, s. 426; Rozmowa z Sewerynem Blumsztajnem, Joanna Joanna Szczęsna i Januszem Przewłockim, [w:] Niepokorni. Rozmowy o Komitecie Obrony Robotników. Relacje członków i wspótpracowników Komitetu Obrony Robotników zebrane w 1981 roku przez Andrzeja Friszke i Andrzeja Paczkowskiego, Kraków 2008 , s. 423.

94. A. Friszke, "Biuletyn Informacyjny" KOR i KSS „KOR” (1976-1980), [w:] Drugi obieg w PRL na tle samizdatu w państwach bloku sowieckiego po 1956 roku, red. P. Gasztold-Seń, N. Jarska, J. Olaszek, Warszawa 2016, s. 251. 
ludzie nie zapomnieli roku 70-go. Pytani o swoją działalność i jej dalsze perspektywy przedstawiciele WZZ są bardzo powściągliwi. «To jeszcze wszystko w powijakach», «przypomina się wiek XIX». Nie stronią od gorzkiej prawdy: ludzie w zakładach pracy są zastraszani i podzieleni. Można ich nie tylko terroryzować, lecz i korumpować: mieszkanie, lepsza lub gorsza praca i zarobki zależne są często nie tyle od kwalifikacji, co od posłuszeństwa, a w wyższych kręgach to i talon na samochód - monopolistyczna władza dysponuje właściwie wszystkim, może dowoli używać metody bata i cukierka". Zieleński akcentował, że celem działaczy WZZ jest pomoc robotnikom w samoorganizowaniu się, nie zaś kierowanie ich działalnością. Podawał konkretne przykłady działań, zarówno sukcesów, jak i porażek.

Zieleński wymienił z nazwiska działaczy podpisujących dokumenty WZZ: Andrzeja Bulca, Andrzeja Gwiazdę, Edwina Myszka ${ }^{95}$, oraz ich wspótpracowników: Błażeja i Krzysztofa Wyszkowskich, Joanny Dudy-Gwiazdy, Aliny Pienkowskiej, Lecha Wałęsy (który został po raz pierwszy w prasie drugiego obiegu nie tylko wspomniany, ale i szerzej przedstawiony czytelnikom jako dzielny, wielokrotnie represjonowany działacz) i działacza KOR Bogdana Borusewicza. 0 działaniach władz wobec tych ludzi pisał: „Trudno się dziwić, że bezpieka i współpracujące $z$ nią dyrekcje chcą za wszelką cenę skompromitować jawnych członków WZZ, choć próby te najczęściej kompromitują samych inspiratorów. Przystąpili do Wolnych Związków Zawodowych ludzie rozmaici. Co ich łączy? - Są to osoby w wieku 20-40 lat, a więc wychowane całkowicie w PRL-u, co więcej - przeważnie ludzie związani z przemysłem morskim, który jest tego PRL-u chlubą. Takim trudno przylepić etykietkę reakcjonistów, obszarników, rewizjonistów czy syjoni- stów. Choć oczywiście, wzorem towarzysza Kliszki, można sobie ukuć powiedzenie, że kontrrewolucja kryje się teraz w kombinezonach robotników. Są to na pozór zwyczajni ludzie, statystycznie przeciętni obywatele PRL. Większość żonata, dzieciata, kiepsko mieszkająca i stojąca w kolejkach. Taki Wałęsa to ma nawet czworo dzieci. Na ogół nie znali się przedtem, nie byli nawet w grupie przyjacielskiej, połączyła ich działalność związkowa. Trafiali do niej różnie: na przykład Alina Pieńkowska, pielęgniarka, znalazła w «Robotniku» adres Bogdana Borusewicza i przyszła do niego tak wprost z ulicy. I aż dziwne: z jednej strony cały aparat partii, bezpieki, administracji, z monopolem władzy nieograniczonej, z pałkami i funduszami (200 tys. za łebka!), jedyni dysponenci dóbr, dyktujący i dyrekcjom i sądom, co chcą. Z drugiej garstka, zdawałoby się śmieszna, zwykłych zjadaczy chleba, którzy nie mają nic, a którym w każdej chwili można zrobić wszystko. A jednak tamci boją się ich. I to coraz bardziej"96. Zieleński napisał kilka tekstów na zamówienie „Robotnika"97. Nie sygnował ich jednak swoim głównym pseudonimem, w związku z czym trudno je zidentyfikować, możliwe, że były niepodpisane. "Robotnik" jako pismo o niewielkiej objętości nie mógł drukować reportaży, w których specjalizował się Zieleński. Jednocześnie krótkie teksty o sytuacji konkretnych zakładów pracy i bolączkach pracujących tam robotników pasowały do jego zainteresowań. Kierująca redakcją tego pisma Helena Łuczywo po latach nie pamiętała, pod jakim pseudonimem pisywał Zieleński; pamiętała tylko, że pisywał teksty publicystyczne dotyczące spraw krajowych ${ }^{98}$. Współpracę Zieleńskiego $\mathrm{z}$ „Robotnikiem" potwierdzają też dokumenty $\mathrm{z}$ jego inwigilacji, odnotowujące jego spotkanie z Heleną Łuczywo ${ }^{99}$.

95. Edwin Myszk wkrótce został zdemaskowany jako tajny współpracownik SB.

96. W. Jasiński [J. Zieleński], Ludzie zwyczajni, „Biuletyn Informacyjny” XII 1978, nr 25, s. 27-30.

97. Rozmowa z Janem Lityńskim, [w:] Niepokorni..., s. 392.

98. List Heleny Łuczywo do Jana Olaszka (2020).

99. AIPN, 00191/157, Zdjęcia wykonane przez Biuro „B”, k. 135; ibidem, Komunikat w sprawie obserwacji, 17 XII 1979, k. 138; ibidem, Ustalenie, 27 XII 1979, k. 140. 
Drugą formą opozycyjnego zaangażowania Zieleńskiego był w udział w pracach Konwersatorium „Doświadczenie i Przyszłość". Inicjatorem jego powstania w listopadzie 1978 roku był wspomniany już parokrotnie Stefan Bratkowski. Inicjatywa ta miała charakter nieformalnego klubu dyskusyjnego i sytuowała się niejako w szarej strefie między liberalnym skrzydłem PZPR a opozycją. W skład Konwersatorium wchodzili oprócz Zieleńskiego między innymi znani naukowcy, dziennikarze i działacze katoliccy Klemens Szaniawski, Andrzej Wielowieyski, Jan Strzelecki, Jan Malanowski, Kazimierz Dziewanowski i Wojciech Adamiecki. Zadaniem "DiP" było diagnozowanie stanu państwa w różnych sferach życia i proponowanie dróg jego naprawy. Zieleński do tej inicjatywy trafił poprzez ankietę rozesłaną przez twórców "DiP" z prośbą o opisanie problemów Polski w dziedzinie, którą się zajmowali. Wśród osób, od których szybko przyszła odpowiedź, był bohater tego tekstu ${ }^{100}$. Należał on do najbardziej zaangażowanych uczestników całej inicjatywy ${ }^{101}$. Zajmował się między innymi rozprowadzaniem kolejnych ankiet ${ }^{102}$. Mimo że "DiP" nie został dobrze przyjęty w środowisku korowskim jego działacze uważali, że rozmywa on podział na władzę i opozycję - nie było problemem łączenie aktywności w inicjatywie Bratkowskiego z pisaniem do niezależnej prasy drukowanej przez środowisko korowskie. Oprócz Zieleńskiego postępowali tak również Dziewanowski i Adamiecki ${ }^{103}$.

Zieleński uczestniczył w wielu różnych spotkaniach środowiska opozycyjnego. Niektóre z nich odbywały się przy ulicy Wałowej w mieszkaniu Elżbiety Gutkowskiej, z którą był związany. Pojawiało się tam wiele osób ze środowiska korowskiego.
Polityka łączyła się wówczas z życiem towarzyskim opozycji. Tworzący ją ludzie regularnie spotykali się na rozmaitych bankietach. Zieleński jako człowiek o dużym poczuciu humoru, lubiący życie towarzyskie, świetnie odnajdywał się w tych kręgach. Na jednym ze zdjęć zrobionych na przyjęciu $\mathrm{z}$ okazji wydania ostatniego numeru "Biuletynu Informacyjnego" (już po powstaniu Solidarności) widać stojącego na krześle Zieleńskiego, którego słucha stłoczona grupa opozycjonistów. Są tam Jacek Kuroń i jego żona Gajka, drukarz NOW-ej i „Robotnika” Andrzej Zieliński, Jan Tomasz Lipski (współpracownik KOR, syna Jana Józefa) oraz redaktor "Biuletynu Informacyjnego" Janusz Przewłocki ${ }^{104}$.

Opozycyjna działalność Zieleńskiego budziła coraz większe zainteresowanie SB. W styczniu 1980 roku powstał plan pozyskania go do współpracy z policją polityczną. Sporządzono wówczas jego charakterystykę, opierającą się przede wszystkim na dokumentach wystawianych mu w poprzednich miejscach pracy - między innymi z 1955 roku. „Mimo stosunkowo długiego czasu, jaki upłynął od momentu wystawienia tej opinii, jego cechy charakteru nie uległy zasadniczym zmianom. Dość kłopotliwym charakterem tłumaczyć należy częste zmiany pracy kandydata" - komentowali funkcjonariusze, nie wspominając, że przynajmniej dwukrotnie zmiana miejsca pracy wynikała z kontekstu politycznego. Wydaje się, że wiedza SB na jego temat nie była więc zbyt głęboka. Funkcjonariusz zamierzał powiedzieć Zieleńskiemu, że spotkanie $\mathrm{z}$ nim jest spowodowane jego kontaktami $\mathrm{z}$ Janiną Jankowską i Heleną Łuczywo. Cały przebieg spotkania został starannie zaplanowany, funkcjonariusz rozpisał nawet kilka jego wariantów.

100. A. Friszke, Opozycja polityczna..., s. 517.

101. AIPN, 00191/157, Wyciąg z informacji TW ps. "Stanisław” z dnia 20 XII 1979, 22 XII 1979, k. 73-74.

102. Ibidem, Informacja dotycząca Jerzego Zieleńskiego, 6 III 1980, k. 120.

103. J.J. Lipski, KOR. Komitet Obrony Robotników, Komitet Samoobrony Społecznej, wstęp A. Friszke, oprac. G. Waligóra, Warszawa 2006, s. 430; A. Friszke, Czas KOR-u. Jacek Kuroń a geneza Solidarności, Kraków 2011, s. 452.

104. Relacja Barbary Zieleńskiej (2019).

105. AIPN, 00191/157, Plan działań operacyjnych zmierzających do pozyskania do współpracy Jerzego Zieleńskiego, 10 I 1980, k. 46-51. 
Rozmowa miała być prowadzona w kierunku poszukiwania wspólnej płaszczyzny działania dla dobra kraju. Funkcjonariusz zamierzał zaproponować Zieleńskiemu rolę „konsultanta”, z którym omawiano by problemy interesujące SB. Podkreślał przy tym, przypominając zdecydowaną odmowę współpracy Zieleńskiego z 1957 roku, że nie należy używać określenia „współpraca z SB". Drugi wariant rozmowy miał polegać na dopytywaniu się o motywacje, którymi kierował się Zieleński, utrzymując kontakty z opozycją, oraz na przekonywaniu go do tego, że zwalczanie "wrogiej zorganizowanej działalności" jest obowiązkiem każdego obywatela. W ostateczności pracownik policji politycznej zamierzał zaszantażować go ujawnieniem faktu jego dawnej współpracy z SB ${ }^{105}$. Przełożony autora dokumentu zasugerował odstąpienie od rozmowy ze względu na represje podjęte wobec osób bliskich Zieleńskiemu - przeniesienie Elżbiety Gutowskiej na inne stanowisko w związku z jej kontaktami z dziennikarzem i zwolnienie Janiny Jankowskiej z pracy w radiu (do którego wówczas nie doszło). Sprawę Zieleńskiego postanowiono odłożyć na kilka miesięcy ${ }^{106}$.

\section{Karnawał Solidarności?}

Kiedy w lipcu 1980 roku rozpoczęła się fala protestów robotniczych, Jerzy Zieleński, podobnie jak członek KSS „KOR” Wojciech Onyszkiewicz, przekazywał Jackowi Kuroniowi (który prowadził swego rodzaju centrum informacyjne i utrzymywał stały kontakt z Radiem Wolna Europa) informacje na temat tego, co się działo w Lublinie ${ }^{107}$. Onyszkiewicz i Zieleński działali tam niezależnie od siebie ${ }^{108}$. Gdy zaczął się strajk w Stoczni Gdańskiej, Zieleński był jednym z sygnatariuszy Apelu 64, sygnowanego przez intelektualistów wyrażających wsparcie dla protestujących ${ }^{109}$. Zieleński w czasie strajku znalazł się na terenie stoczni, czego efektem był napisany dla „Biuletynu Informacyjnego" reportaż Strefy wyzwolone. Opisywał w nim swoje wrażenia od chwili pojawienia się w stoczni. Zwracał uwagę na symbole narodowe, portret Jana Pawła II na bramie i krzyż upamiętniający ofiary Grudnia '70. Pisał też o reakcjach protestujących na pojawienie się przedstawicieli mediów: „W bramie wartownicy w biało-czerwonych opaskach czujnie sprawdzają dokumenty, dziennikarzy z oficjalnych środków przekazu traktują grzecznie, ale ta grzeczność ma swoje gradacje i odcienie, zależnie od tego, na ile w danym dniu prasa - głównie warszawska uprawiała polowanie na czarownice «sił antysocjalistycznych». Pewni przedstawiciele tej prasy zostali wyproszeni ze stoczni - w tym zasłużeni jeszcze od 1976 roku; robotnicy są nierychliwi, ale sprawiedliwi. Inni słyszą często: po co tu siedzicie? I tak albo skłamiecie, albo nic nie napiszecie. Każdy musiał przełknąć gorzką pigułkę za długi okres propagandy sukcesu, bo czyż nie wszyscy ponoszą odpowiedzialność choćby za milczenie?".

Nastrój w stoczni przypominał mu grecką agorę. Za główny temat prowadzonych tam rozmów uznawał wolność słowa i swobody obywatelskie. "Stocznia - była wielką szkołą demokracji bezpośredniej. Dla wszystkich. Wałęsa czasami pytał wprost z sali prezydialnej: «No co, zgoda? Dobrze tak będzie?» - a mniejsze lub większe oklaski Sali, delegatów są barometrem nastroju i nieraz wpływają na stanowisko prezydium w rozmowach z rządem. Wyrazem najwyższej aprobaty jest «Jeszcze Polska...»". Zieleński opisał też przebieg strajków w Elblągu i w Gdyni, które to miasta również w tym gorącym okresie odwiedził. Cały reportaż kończył słowami: "Ostatnia niedziela. Ostatni dzień, w którym stoją żurawie. Nastrój odprężenia i zwycięstwa.

106. Ibidem, Notatka służbowa, 21 I 1980, k. 53.

107. J.J. Lipski, KOR..., s. 535.

108. Relacja Wojciecha Onyszkiewicza (2020).

109. Archiwum 0środka KARTA, Archiwum Opozycji, IV/04.05.43, Apel 64 intelektualistów, 20 VIII 1980, bp. 
Sierpień Anno 1980 w Stoczni Gdańskiej: nieruchome kadłuby statków, nieruchome chmury odbite w wodzie, słońce, jarzębina czerwienieje - od jutra nowy rozdział historii"110.

W pierwszych dniach po podpisaniu porozumień sierpniowych w środowisku dziennikarzy powstała idea przeprowadzenia zmian w Stowarzyszeniu Dziennikarzy Polskich. Zieleński należał do osób najbardziej zaangażowanych w ten proces ${ }^{111}$. Według ustaleń SB wówczas ostro atakował cenzurę i Komitet ds. Radia i Telewizji ${ }^{112}$. Kluczowym momentem było walne zebranie stowarzyszenia, które odbyło się 11 września w jego siedzibie. Barwnie przebieg tego spotkania opisał w swoich wspomnieniach dziennikarz prasy Stronnictwa Demokratycznego Marek Rapacki: „Na Foksal temperatura była gorąca, bo dni wciąż niezwykłe. Wywiązała się emocjonalna dyskusja. W imieniu zespołu czołowego tygodnika (który zresztą zasłużył się później w dobrej sprawie) wybitny publicysta deklarował ostrożną aprobatę, choć zachęcał do umiaru, bo nasza ulga i radość ze zwycięstwa mogły się łatwo okazać zwodnicze. Pod koniec zebrania nieznany mi wtedy dziennikarz, średniego wzrostu, lekko siwiejący blondyn około pięćdziesiątki, na zasadzie «podaj dalej»: zachęcał, by przejść potem do połączonej z kinową sali konferencyjnej i tam kontynuować w węższym gronie - chcących coś dalej z tym wszystkim robić. A gdy przeniosła się tam chyba z połowa zebranych, użył - przekornie - określenia «grupa inicjatywna» kojarzącego się z gromadką komunistycznych działaczy i agentów, którzy za niemieckiej okupacji formowali Polską Partię Robotniczą (PPR). My mieliśmy stanowić zespół dziennikarzy chcących wspierać w mediach (i nie tylko w mediach) zdobycze Sierp- nia. To był Jurek Zieleński - Ziel, jak go wkrótce, wraz z jego dotychczasowymi znajomymi zacząłem nazywać"113. Taką rolę odegraną przez Zieleńskiego potwierdza relacja Janiny Jankowskiej ${ }^{114}$.

Chociaż bohater tego tekstu był ogromnie zaangażowany w proces przemian w SDP, to nie chciał kandydować do nowych władz stowarzyszenia. Janina Jankowska wspominała, że Zieleński zdecydował się na taką z postawę ze względu na swoją współpracę z UB i jej ewentualne konsekwencje: „Jurek nie chciał kandydować do władz ani wygłaszać żadnych publicznych przemówień. Nie chciał być na pierwszej linii, żeby się go nie czepiali"115. Funkcjonariusze policji politycznej często w podobnych sytuacjach próbowali nakłaniać ludzi do ponownego nawiązania współpracy, niekiedy szantażując ich jej ujawnieniem. Jednocześnie Jankowska podkreślała, że Zieleński, nie pełniąc żadnej oficjalnej funkcji w stowarzyszeniu, wykonywał ogromną pracę na rzecz zachodzących w nim przemian ${ }^{116}$.

Na taką postawę Zieleńskiego mogło też wpłynąć to, że chciał angażować się przede wszystkim w działania Solidarności, która była głównym motorem zachodzących w Polsce przemian. Zwracał na to uwagę Marek Rapacki: „Jurek był duszą przygotowań w grupie inicjatywnej, ale ostatecznie nie chciał być delegatem na Zjazd [SDP], a więc i członkiem nowych władz. Bez wątpienia uważał, że ze względu na specyfikę dziennikarskiego środowiska jako całości nawet odnowione SDP nie będzie taką organizacją, w której mógłby mówić pełnym głosem i w tak niezwykłych czasach wolał się skoncentrować na pracy gdzie indziej, w opozycji - w związku «Solidarność». Nierzadko bywał jednak na różnego rodzaju spotkaniach na Foksal i nie

110. J. Zieleński, Strefy wyzwolone, "Wolność i Solidarność. Studia z dziejów opozycji wobec komunizmu i dyktatury” 2010, nr 1,

s. 13-142. Pierwodruk: „Biuletyn Informacyjny” 1980, nr 6.

111. D. Wicenty, Załamanie na froncie ideologicznym..., s. 42-43.

112. Informacja operacyjna dotycząca przebiegu zebrania członków SDP, 11 IX 1980, [w:] ibidem, s. 237.

113. M. Rapacki, Wspomnienie o Zielu, http://www.jerzyzielenski.pl/wspomnienia2.html (dostęp: 19.06.2020).

114. Relacja Janiny Jankowskiej (2020).

115. Ibidem.

116. Ibidem. 
rezygnował z wpływu na kierunek naszych prac. Nie ma co ukrywać, że był radykałem. Ponieważ mnie - znacznie mniej od Niego doświadczonemu - na działalności w Radzie SDP zależało (tam nie bez racji uchodziłem za jednego z radykałów czasem niewygodnych), ale mocno zaangażowałem się też w działalność (głównie prasową) w Regionie «Mazowsze» NSZZ «S», weszliśmy w bliższą ze sobą komitywę. W styczniu on prowadził na Foksal spotkania przygotowawcze przed walnym, wyborczym zebraniem Warszawskiego Oddziału Stowarzyszenia. A ja mu asystowałem. Raz czy dwa było i tak, że gdzieś z tylnych rzędów czy z kuluarów przysłuchiwał się posiedzeniom Rady i w przerwie, trochę zniecierpliwiony zwrócił się do mnie: «nie traćmy czasu, chodź, idziemy do nas, na Mokotowską» (czyli do ówczesnej siedziby Regionu)"117.

Jerzy Zieleński był stałym bywalcem siedziby Regionu. Rewolucja Solidarności była jego rewolucją. Zaangażowanie w działania organizacyjne sprawiło jednak, że musiał odłożyć na bok swoje plany pisarskie, na przykład książkę o Dezyderym Chłapowskim, pionierze poznańskiego rolnictwa ${ }^{118}$. W jego ówczesnych felietonach, drukowanych w „Wiedzy i Życiu”, zaczęły pojawiać się aluzje polityczne. Na przykład w jednym z tekstów sugerował, że dowodem na demokratyzację po Sierpniu ' 80 było dla niego nie samo pojawienie się Solidarności, ale zniknięcie... "kanarów tajniaków”. Wspominał przy tym o sprawie opozycyjnego Teatru Ósmego Dnia, która zaczęła się od braku biletów na przejazd komunikacją miejską, a skończyła „jako proces parapolityczny". Tekst zakończyło wymowne postscriptum o tym, że podobno "kanary-tajniaki" znów się pojawiły. „Przestrzegam przed wyciąganiem pochopnych wniosków, ale informuję dla porządku"119. Zieleński o procesie Teatru Ósmego Dnia mówił nieprzypadkowo. Dobrze znał jego przebieg, bo wraz z Janiną Jankowską był na nim obecny, co odnotowała SB, której funkcjonariusz zrobił im zdjęcia przed budynkiem sądu ${ }^{120}$.

Jesienią 1981 roku Jerzy Zieleński był uczestnikiem I Krajowego Zjazdu Delegatów NSZZ "Solidarność" w Gdańsku. Parokrotnie zabierał głos w czasie obrad. Z jego wypowiedzi wyłania się obraz człowieka w pełni utożsamiającego się z ruchem społecznym. Zieleński wypowiedział się na przykład za elastycznym podejściem do porządku obrad, podkreślając, że "uchwalał go zjazd i zjazd go może doskonalić" ${ }^{121}$. Zabierał głos również na temat kształtu Komisji Krajowej, czyli ogólnopolskich władz Solidarności ${ }^{122}$, i dostępu do członkostwa w związku zawodowym dla bezrobotnych ${ }^{123}$. Zwrócił uwagę na potrzebę przeczytania przez delegatów tekstu jednej z uchwał, nie chcąc poprzestać na wysłuchaniu jej treści ${ }^{124}$. Był też jednym z wnioskodawców projektu uchwały dotyczącej stanu przygotowania Polski do zimy ${ }^{125}$.

Najszerzej wypowiadał się w związku z dyskutowaną wówczas między władzą a Solidarnością sprawą samorządów robotniczych. W sprawie tej Sejm PRL uchwalił zasadę powoływania i odwoływania dyrektora zakładu pracy przez samorząd (w wyjątkowych przypadkach decyzję taką mogłyby podjąć władze, ale musiałyby ją skonsultować z radą

117. M. Rapacki, Wspomnienie o Zielu.

118. AIPN, 00191/157, Konspekt książki o Dezyderym Chłapowskim, tytuł roboczy: „Oficer spóźnionych nadziei” albo „Koń a sprawa polska", k. 329; B. Zieleńska, Jerzy Zieleński, publicysta; S. Bratkowski, Zanim się wycofał.

119. Idem, Listy do samego siebie, "Wiedza i Życie” 1981, nr 573, s. 30.

120. AIPN, 00191/157, Zdjęcia wykonane przez Biuro „B".

121. I Krajowy Zjazd Delegatów NSZZ "Solidarność". Stenogramy, t. 1: I tura, oprac. G. Majchrzak i J.M. Owsiński, wstęp B. Kaliski, Warszawa 2011, s. 308.

122. Ibidem, s. 405.

123. Ibidem, s. 617.

124. I Krajowy Zjazd Delegatów NSZZ "Solidarność". Stenogramy. t. 2: II tura, oprac. G. Majchrzak i J.M. Owsiński, cz. 2, Warszawa 2013, s. 646-647.

125. I Krajowy Zjazd Delegatów NSZZ "Solidarność". Stenogramy, t. 2, cz. 1, s. 450-451. 
robotniczą) ${ }^{126}$. Było to rozwiązanie kompromisowe, które część uczestników zjazdu krytykowała' ${ }^{127}$. Stanowisko Jerzego Zieleńskiego w tej sprawie było przeciwne: „Proszę państwa, kiedy coś czynię albo oceniam, nie mając pełnego rozeznania - jak właśnie obecnie, bo nie jestem znawcą ani ekonomiki, ani gospodarki, a tym mniej prawa - staram się, jak w każdej grze, po reakcji przeciwnika wywnioskować, czy słusznie uczyniłem. Jak zareagowała strona przeciwna na kompromisowy zapis w ustawie? Zareagowała naciskami poprzez klub PZPR w Sejmie, żeby go zmienić lub w ogóle usunąć. W rezultacie doprowadziło to po raz pierwszy od lat chyba trzydziestu albo i więcej do rebelii w Sejmie, tym Sejmie, o którym wiemy, jak został wybrany i jak się na ogół zachowuje. Jest to dla nas fakt polityczny dodatni, temu Sejmowi nie powinniśmy już grozić bojkotem w tej chwili - może w następnej, jeśli znowu zmieni front. Bo to by oznaczało, że odrzucamy układ dla siebie korzystny. Sądzę, że pośrednio, w kompromisowym zapisie możemy upatrywać i innych dla siebie korzyści. Inne pytanie, które bym sobie zadał przy ocenie tego faktu, to: jeśli odrzucimy kompromis, co dalej? Referendum ogólne, powszechne, miało sens przed uchwaleniem ustawy, moim zdaniem. Nie sądzę, żebyśmy mogli iść teraz na strajk generalny, nawet w tak zasadniczej sprawie. Nie jestem przekonany co do tego, że wszyscy albo nawet większość naszego związku jest tak radykalna, jak to się tutaj na tej sali mówi. Zmęczenie robi swoje. W tej sytuacji zadałbym jeszcze trzecie pytanie: co uczyni przeciwnik, gdy odrzucimy zapis kompromisowy? Gdy odrzucimy tę ustawę w jej brzmieniu. Czy będzie naprawdę na nas zły, czy też będzie rad? Ja myślę, że pierwsze, co zrobi przeciwnik, to obciąży nas odpowiedzialnością za odłożenie reformy gospodarczej, o czym tylko marzy, dlatego że jest do niej kompletnie nieprzygotowany. Kończąc swoje wystąpienie, chcę powiedzieć, że czasy się zmieniają i my się w nich bardzo szybko czasem zmieniamy. Kilka miesięcy temu wielu kolegów, którzy teraz bardzo ostro wypowiadają się w tej sprawie, w ogóle nie chciało słyszeć o żadnym samorządzie pracowniczym, i to niniejszym kolegom przypominam"128.

W podobnym duchu Zieleński wypowiadał się w sprawie pomysłu utworzenia przez Solidarność Społecznej Rady Gospodarki Narodowej: „Proszę państwa, mnie się wydaje, że ten projekt z Radą Gospodarki idzie za daleko, ponieważ jest to projekt przejęcia części władzy gospodarczej, a więc i części odpowiedzialności, bez odpowiednich do tego warunków, ponieważ cały aparat administracyjny znajduje się w rękach strony przeciwnej. Ja nie wiem, czy w ogóle mamy mandat od naszych wyborców na podejmowanie decyzji o przejmowaniu części władzy. Ja takiego mandatu nie czuję, ja takiego upoważnienia od swoich wyborców nie mam. Merytorycznie natomiast będzie to niesłychanie trudne do przeprowadzenia, jak powiadam, w warunkach, w których cały aparat administracyjny pozostał ten sam i jest przeciwko nam. Mnie się wydaje, że mamy być tym pistoletem przystawionym do głowy rządu w obronie praw pracowniczych, my mamy bronić praw pracowniczych, a nie przejmować władzę gospodarczą kraju. A nawet jej części"129.

Tak wyrażone poglądy, jak się wydaje, wpisywały się w podejście Jerzego Zieleńskiego do życia $i$ jego niechęć do romantycznych zrywów. Wydaje się, że po początkowym okresie solidarnościowego karnawału był on pełen entuzjazmu. Tak wynikałoby ze wspomnienia Stefana Bratkowskiego: „Sierpień i Solidarność powitał z uczuciem sukcesu i nadziei - czekaliśmy blisko 25 lat na podobny jak w Październiku 1956 wielki zryw robotników, który znowu

126. A. Friszke, Rewolucja Solidarności 1980-1981, Kraków 2014, s. 661.

127. Ibidem, s. 662-663; B. Kaliski, Zjazd Solidarności - fakty i konteksty, [w:] I Krajowy Zjazd Delegatów NSZZ "Solidarność". Stenogramy, t. 1, s. 36-37.

128. I Krajowy Zjazd Delegatów NSZZ "Solidarność. Stenogramy, t. 2, cz. 1, s. 157.

129. Ibidem, s. 655-656. 
swą masowością wymusi zmiany. Wobec wcale nie tak znowu optymistycznych prognoz ze strony ludzi, którzy znali dobrze panujący reżim i sowiecką nad nim kontrolę, uważaliśmy, że trzeba w tym ruchu być bardzo uważnym - po doświadczeniu porażki Października. Jurek nie chciał tego słuchać [...]. Był już rewolucjonistą. Kiedy uprzedzaliśmy go po pierwszych w maju 1981 r. wiadomościach o przygotowywanym wojskowym zamachu stanu [...]. Jurek nie wierzy $\ell^{\prime \prime 130}$. Jesienią 1981 roku był znacznie bardziej pesymistyczny, o czym świadczą słowa Bratkowskiego o czasie poprzedzającym 13 grudnia 1981: "Od kilkunastu dni mówit, że «jeśli jeszcze raz, to go to już nie interesuje». Wiedzieliśmy w naszym gronie od kilku tygodni, dostawszy bezpośrednie potwierdzenie od przyjaciół z armii, o szykowanym wojskowym zamachu stanu 13 grudnia [...], nie traktowaliśmy deklaracji Jurka specjalnie serio, machaliśmy rękami - «nie opowiadaj głupstw», «jeśli, to będziemy jeszcze bardziej potrzebni», na co odpowiadał - «beze mnie»"131. Janina Jankowska wspominała nastrój swojego przyjaciela w czasie zjazdu: "on miał w sobie taki smutek. Mówit, że z tego nic nie wyjdzie. Myśmy wtedy jeszcze byli w euforii, a u Jurka już wtedy przekonanie, że oni nam nie pozwolą"132. Podoba była wymowa wspomnienia Jerzego Szperkowicza z listopada 1982 roku: „W pewnej rozmowie o doświadczeniach młodzieńczych powiedział, że na żadne koszmary on się więcej nie pisze. Nikt nie rozpoznał postanowienia"133.
Jesienią 1981 roku przed Jerzym Zieleńskim pojawiło się największe zawodowe wyzwanie - stworzenie własnej gazety. Na początku listopada Zarząd Regionu Mazowsze powołał go na stanowisko redaktora naczelnego tygodnika "Mazowsze"134. Miał to być ukazujący się w oficjalnym obiegu tygodnik regionalny. Jego nazwa, "Mazowsze”, miała wyraźnie wskazywać na bezpośrednie związki z kierownictwem regionu. Planowano bardzo wysoki nakład pisma - 250 tysięcy egzemplarzy ${ }^{135}$. Zieleński bardzo mocno zaangażował się w tworzenie swojej pierwszej w życiu własnej redakcji. Zaczął budować zespół. Jego zastępcą miał być Marek Rapacki ${ }^{136}$. Do zespołu mieli też wejść czołowa dziennikarka prasy korowskiej Joanna Szczęsna, młody dziennikarz Tomasz Sypniewski, wspominany juz parokrotnie Wojciech Adamiecki oraz publicysta zajmujący się tematyką społeczną Stefan Ancerewicz. Sekretarzem redakcji miał być Seweryn Blumsztajn, ale w pewnym momencie wyjechał do Francji ${ }^{137}$. Zieleński obawiał się, że nie poradzi sobie $\mathrm{z}$ administracyjnymi i finansowymi aspektami pracy redaktora naczelnego. Jego stryjeczna siostra Bogumiła Zieleńska, która była ekonomistką, obiecała mu jednak pomoc w tej kwestii ${ }^{138}$. "[...] gorączkowe, trochę bezładne przygotowania przebiegały w warunkach rosnącego napięcia w kraju; chwilami miałem (chyba wszyscy mieliśmy) poczucie, że spotykamy się, planujemy, spieramy, pogrążeni w jakiejś nierzeczywistości, bez szans na konkretny efekt" - wspominał Marek Rapacki ${ }^{139}$.

130. S. Bratkowski, Zanim się wycofał.

131. Ibidem.

132. Relacja Janiny Jankowskiej (2020).

133. J. Szperkowicz, W rocznicę Ziela, s. 54.

134. A. Friszke, Regionalny Komitet Wykonawczy Mazowsze. Powstanie, struktura, działalność (1981-1986), [w:] Solidarność podziemna 1981-1989, red. A. Friszke, Warszawa 2006, s. 408; idem, Region Mazowsze NSZZ "Solidarność", [w:] "Solidarność" od wewnątrz 1980-1981, red. A. Friszke, K. Persak, P. Sowiński, Warszawa 2013 s. 123. W niektórych biogramach Zieleńskiego pojawia się nieprecyzyjna informacja, że został redaktorem naczelnym „Tygodnika Mazowsze”. Oficjalna nazwa tego pisma brzmiała po prostu "Mazowsze".

135. Archiwum Akt Nowych [dalej: AAN], GUKPPiW [Dalej: Główny Urząd Kontroli Prasy, Publikacji i Widowisk], 2967, Wniosek NSZZ "Solidarność” Region Mazowsze o wydanie związkowego tygodnika regionalnego pt. „Mazowsze”, 25 XI 1981 r., bp.

136. Relacje Marka Rapackiego (2010) i Bogumiły Zieleńskiej (2020).

137. Relacje Barbary Zieleńskiej (2019) i Janiny Jankowskiej (2020); M. Rapacki, Wspomnienie o Zielu.

138. Relacja Bogumiły Zieleńskiej (2020).

139. M. Rapacki, Wspomnienie o Zielu. 
Koniec 1981 roku dawał Zieleńskiemu wiele powodów do przeciwstawnych emocji. Z jednej strony wkrótce miała urodzić się jego córka z nowego związku z Anną Tabaczyńską, dziennikarką również zaangażowaną w przemiany w SDP i Solidarność (Marianna Zieleńska przyszła na świat już po śmierci ojca). Z drugiej strony jednak mniej więcej w tym samym czasie o Zieleńskim po raz kolejny przypomniała sobie SB. Janina Jankowska wspominała, że skarżył się on na to, że nachodzi go ten sam funkcjonariusz, z którym spotykał się w latach pięćdziesiątych ${ }^{140}$. „Jurek żył w napięciu. Na jednym z prywatnych spotkań powiedział mi, że odwiedził go SB-ek, który przed laty był jego prowadzącym. To nie rozmawiaj z nim - powiedziałam, bo rzecz wydawała mi się prosta. Ale prosta nie była" - pisała po latach Jankowska ${ }^{141}$. Wszystkie te okoliczności sprawiły, że Zieleński żył w tym czasie w ogromnym stresie $^{142}$. W końcu przeszedł załamanie nerwowe i trafił do szpitala na Hożą ${ }^{143}$. Ze wspomnień Bratkowskiego wynika, że Zieleńskim opiekował się zaprzyjaźniony z nim lekarz Józef Wojnowski ${ }^{144}$. W szpitalu poza bliskimi mieli go jednak odwiedzać także jacyś inni ludzie ${ }^{145}$. Nie można wykluczyć, że również tam nękali go funkcjonariusze SB (Janina Jankowska podejrzewa, że odwiedził go właśnie nachodzący go wcześniej funkcjonariusz ${ }^{146}$, ale nie sposób tego zweryfikować).

Wiadomość o uderzeniu przez władze PRL w Solidarność musiała być dla Jerzego Zieleńskiego tak wielkim szokiem, że 13 grudnia 1981 roku popełnił samobójstwo, wyskakując ze szpitalnego okna. Waldemar Kuczyński i Maciej Łukasiewicz w swoich dziennikach nazwali Zieleńskiego pierwszą ofiarą stanu wojennego ${ }^{147}$. Przez ponad miesiąc kolegom Zieleńskiego z "Życia Warszawy" nie wydawano zgody na publikację nekrologu. Ponadto w latach 1982 i 1984 blokowano w "Odrze" druk wspomnienia o Zieleńskim, które napisał Szperkowicz ${ }^{148}$. To dlatego ten tekst ukazał się dopiero w roku 1985. W kręgach opozycyjnych pojawiło się podejrzenie, że nie było to samobójstwo, lecz efekt działań policji politycznej. Brak jednak jakichkolwiek wskazujących na to źródeł oraz ewentualnego motywu, który miałby stać za podjęciem takiego kroku. Również stan, w jakim znajdował się Zieleński, wskazuje na to, że rzeczywiście było to samobójstwo.

Podziemne Stowarzyszenie Dziennikarzy Polskich uczyniło Jerzego Zieleńskiego patronem nagrody dla młodych dziennikarzy ${ }^{149}$. Nagroda ta została przyznana tylko raz - Michałowi Ogórkowi. Jego pamięć została zaś uczczona w pierwszym numerze już podziemnego „Tygodnika Mazowsze”. Warto odnotować, że pierwszemu wydaniu tego tytułu nadano numer drugi, niewydany pierwszy numer symbolicznie poświęcając zmarłemu redaktorowi ${ }^{150}$. W 2006 roku ustanowiono nagrodę SDP im. Zieleńskiego dla autorów publikacji poświęconych popularyzacji wiedzy o Polsce i świecie. Była przyznawana do roku 2012. W 2002 Rada Etyki Mediów

140. Relacja Janiny Jankowskiej (2020).

141. J. Jankowska, Jerzy Zieleński (świadectwo).

142. Relacje Barbary Zieleńskiej (2019) i Janiny Jankowskiej (2020).

143. M. Rapacki, Wspomnienie o Zielu.

144. S. Bratkowski, Zanim się wycofał.

145. Relacje Barbary Zieleńskiej (2019) i Janiny Jankowskiej (2020).

146. J. Jankowska, Jerzy Zieleński (świadectwo).

147. W. Kuczyński, Burza nad Wisła, Warszawa 2002, s. 221; M. Łukasiewicz, Weryfikacja. Z notatnika stanu wojennego 1981-1982, Warszawa 1994, s. 29.

148. AAN, GUKPPiW, 4033, Informacja bieżąca nr 24, 3 II 1984, k. 19.

149. W. Górecki, "Tygodnik Mazowsze" 1982-1989. Monografia pisma na tle historii drugiego obiegu w Polsce, maszynopis, praca magisterska, Katolicki Uniwersytet Lubelski, 1995, s. 90.

150. Wspomnienie o Jerzym Zieleńskim, „Tygodnik Mazowsze”, 11 II 1982, s. 1; Relacja Heleny Łuczywo, Materiały do filmu Solidarność według kobiet, zebrane przez Martę Dziwo i Piotra Śliwowskiego. 
ustanowiła Nagrodę im. Jerzego Zieleńskiego ${ }^{151}$, której historia również nie była długa.

Na podstawie życiorysu Jerzego Zieleńskiego można pokusić się o kilka refleksji dotyczących PRL. Jego dorobek z okresu po 1956 roku dobrze pokazuje, że nie powinno się całego oficjalnego dziennikarstwa tych czasów sprowadzać do roli tuby propagandowej władz, jak czynią to niektórzy historycy i popularyzatorzy historii ${ }^{152}$. Dziennikarstwa tego nie można oczywiście nazwać niezależnym, z publikowaniem wiązały się bowiem różnego rodzaju kompromisy: powstrzymywanie się od pisania wprost tego, co się myśli, i poruszania niebezpiecznych tematów, niekiedy pisanie rzeczy, z którymi autor nie do końca się zgadzał, ale nie można zgodzić się z zupełnym przekreślaniem dorobku pism społeczno- -kulturalnych czy polskiej szkoły reportażu, a także pism popularyzujących naukę. Mimo ograniczeń cenzury i dyspozycyjności wobec władz można wskazać środowiska, tytuły i osoby, które robiły, mówiąc kolokwialnie, "dobrą robotę".

Historia życia Jerzego Zieleńskiego pokazuje też, że drogi do opozycji w PRL były nieraz kręte i niekoniecznie cały czas prowadziły w jednym kierunku. Bohater tego tekstu przeszedł drogę od przeciwnika systemu po osobę zaangażowaną $\mathrm{w}$ jego tworzenie, od przystosowującego się do rzeczywistości dziennikarza po zdeklarowanego opozycjonistę. Czarno-biały podział na zwolenników i przeciwników władzy, zwłaszcza dla lat 1956-1976, jest niezwykle upraszczający. Ponadto historia Zieleńskiego jest kolejnym przykładem na to, że ludzie uwikłani we współpracę z policją polityczną mogli się z niej uwolnić i uczestniczyć $\mathrm{w}$ autentycznym sprzeciwie wobec władzy.

151. Nagroda Rady Etyki Mediów, "Rzeczpospolita”, 24 VI 2002, s. 2.

152. Zob. np. Na froncie totalitarnego państwa. 0 dziennikarstwie i dziennikarzach w Peerelu ze Sławomirem Cenckiewiczem i Danielem Wicentym rozmawia Jan M. Ruman, „Biuletyn IPN” 2007, nr 12. 


\section{Bibliografia}

I Krajowy Zjazd Delegatów NSZZ "Solidarność". Stenogramy, t. 1: I tura, oprac. G. Majchrzak i J.M. Owsiński, wstęp B. Kaliski, Warszawa 2011.

I Krajowy Zjazd Delegatów NSZZ "Solidarność". Stenogramy. t. 2: II tura, oprac. G. Majchrzak i J.M. Owsiński, cz. 2, Warszawa 2013.

Archiwum Akt Nowych. Główny Urząd Kontroli Prasy, Publikacji i Widowisk, 2967.

Archiwum Instytutu Pamięci Narodowej w Warszawie, 00191/157. Archiwum 0środka KARTA, Archiwum 0pozycji, IV/04.05.43.

Archiwum Uniwersytetu Warszawskiego, 20937.

„Biuletyn Informacyjny” 1980, nr 6.

Bratkowski S., Listy do samego siebie, "Wiedza i Życie” 1981, nr 573.

Bratkowski S., Sens przyzwoitości, „Rzeczpospolita” 2002, nr 145. Bratkowski S., Zieleński J., W tropikach inaczej, Warszawa 1965. Był taki dziennik "Sztandar Młodych", red. W. Borsuk, Warszawa 2006.

Ciborowska E., Leksykon polskiego dziennikarstwa, Warszawa 2002.

Czasopisma społeczno-kulturalne w PRL, red. U. Jakubowska, Warszawa 2011.

Dajcie szansę ziemi, wybór J. Zieleński, Warszawa 1971.

Drugi obieg w PRL na tle samizdatu w państwach bloku sowieckiego po 1956 roku, red. P. Gasztold-Seń, N. Jarska, J. Olaszek, Warszawa 2016.

Friszke A., Czas KOR-u. Jacek Kuroń a geneza Solidarności, Kraków 2011.

Friszke A., Opozycja polityczna w PRL 1945-1980, Londyn 1994. Giełżyński W., Prywatna historia XX wieku, Warszawa 2005.

Górecki W., "Tygodnik Mazowsze" 1982-1989. Monografia pisma na tle historii drugiego obiegu w Polsce, maszynopis, praca magisterska, KUL 1995.

https://encysol.pl/es/encyklopedia/biogramy/19695,Zielenski-Jerzy.html?search=5172117400.

https://studioopinii.pl/archiwa/4396.

http://www.jerzyzielenski.pl/wspomnienia2.html.

Jankowska J., Jerzy Zieleński (świadectwo), maszynopis.

Jasiński W. [J. Zieleński], Ludzie zwyczajni, „Biuletyn Informacyjny" XII 1978, nr 25.
Jasiński W. [J. Zieleński], 0 głupim dowcipie, który zrobiono Ludwikowi Waryńskiemu, "Zapis” 1978, nr 5.

Kuczyński W., Burza nad Wisła, Warszawa 2002.

Lipski J.J., KOR. Komitet Obrony Robotników, Komitet Samoobrony Społecznej, wstęp A. Friszke, oprac. G. Waligóra, Warszawa 2006. List Heleny Łuczywo do Jana Olaszka (2020). List od Barbary Zieleńskiej do Jana Olaszka (2020). Eukasiewicz M., Weryfikacja. Z notatnika stanu wojennego 1981-1982, Warszawa 1994.

Na froncie totalitarnego państwa. 0 dziennikarstwie $i$ dziennikarzach w Peerelu ze Sławomirem Cenckiewiczem i Danielem Wicentym rozmawia Jan M. Ruman, "Biuletyn IPN" 2007, nr 12. Niepokorni. Rozmowy o Komitecie Obrony Robotników. Relacje członków i wspótpracowników Komitetu Obrony Robotników zebrane w 1981 roku przez Andrzeja Friszke i Andrzeja Paczkowskiego, Kraków 2008.

Nagroda Rady Etyki Mediów, „Rzeczpospolita”, 24 VI 2002.

Oblicza prasy Ziem Zachodnich w latach 1945-2012, red. A. Buck, P. Bartkowiak, D. Kotlarek, Zielona Góra 2012.

Persak K., Sprawa Henryka Hollanda, Warszawa 2006.

Relacja Janiny Jankowskiej (2020).

Relacja Heleny Łuczywo, Materiały do filmu Solidarność według kobiet, zebrane przez M. Dziwo i P. Śliwowskiego.

Relacja Wojciecha Onyszkiewicza (2020).

Relacja Barbary Zieleńskiej (2019).

Relacja Bogumiły Zieleńskiej (2020).

"Solidarność" od wewnątrz 1980-1981, red. A. Friszke, K. Persak, P. Sowiński, Warszawa 2013.

Solidarność podziemna 1981-1989, red. A. Friszke, Warszawa 2006.

Szperkowicz J., W rocznicę Ziela, "Odra”, styczeń 1985.

Technika i ja, wybór i oprac. J. Zieleński, Warszawa 1970.

Wicenty D., Załamanie na froncie ideologicznym. Stowarzyszenie Dziennikarzy Polskich od Sierpnia '80 do stanu wojennego, Gdańsk 2012.

Wolne media? Środowisko dziennikarskie w 1989 roku. Studia, red. P. Szulc, T. Wolsza, Szczecin-Warszawa 2010.

Wspomnienie o Jerzym Zieleńskim, „Tygodnik Mazowsze”, 11 II 1982.

www.1944.pl/powstancze-biogramy/jerzy-zielenski,51932.html. Zbiory prywatne Barbary Zieleńskiej, Wspomnienie Krzysztofa Kąkolewskiego o Jerzym Zieleńskim, maszynopis. 
Zieleńska B., Jerzy Zieleński, publicysta, maszynopis.

Zieleński J., A jednak się kręci, Warszawa 1973.

Zieleński J., Demon przychodzi we środy, Warszawa 1974.

Zieleński J., Intruz w świątyni nauki, Warszawa 1980.

Zieleński J., Rejtanowie własnych przywilejów, „Biuletyn Informacyjny" VII-VIII 1979, nr 31/32.

Zieleński J., Strefy wyzwolone, "Wolność i Solidarność. Studia z dziejów opozycji wobec komunizmu i dyktatury" 2010, nr 1. Zieleński J., Sześciu mędrców z Bogatego Szczęścia, Warszawa 1961.

Zieleński J., Wiersze, „Odra”, styczeń 1985, nr 280.

\section{Abstrakt}

W artykule zaprezentowana została droga życiowa dziennikarza Jerzego Zieleńskiego. Omówione zostały jego wojenne losy, postawa powojenna, relacje z komunistyczną policją polityczną, kariera dziennikarska i działalność opozycyjna. Artykuł wpisuje się debatę historiograficzną o ewolucji postaw wobec systemu komunistycznego inteligencji w czasach PRL.

Słowa kluczowe: dziennikarstwo w PRL, opozycja demokratyczna, prasa niezależna, Jerzy Zieleński

\section{Abstract}

The article presents the life path of the journalist Jerzy Zieleński: his wartime experiences, post-war attitudes, relations with the communist political police, journalistic career and opposition activities. The article is a part of the historiographic debate on the evolution of attitudes of intelligentsia towards the communist system in the times of the Polish People's Republic.

Keywords: journalism in the Polish People's Republic, democratic opposition, independent press, Jerzy Zieleński

Jan Olaszek - historyk, pracownik Instytutu Studiów Politycznych PAN i Instytutu Pamięci Narodowej. Badacz opozycji w PRL. Autor książek "Nieliczni ekstremiści". Podziemna Solidarność w propagandzie stanu wojennego (2010), Rewolucja powielaczy (2015), Przeciw PRL. Szkice z dziejów opozycji demokratycznej (2017), Jan Walc. Biografia opozycjonisty (2018), Podziemne dziennikarstwo (2018) i Podziemna sieć społeczna (2020). Współautor książki Holokaust, pamięć, powielacz (2020).

Jan Olaszek is a historian, employee of the Institute of Political Studies of the Polish Academy of Sciences and the Institute of National Remembrance. Researcher of the opposition movement in the Polish People's Republic. Author of several books: "Nieliczni ekstremiści". Podziemna Solidarność w propagandzie stanu wojennego (2010), Rewolucja powielaczy (2015), Przeciw PRL. Szkice z dziejów opozycji demokratycznej (2017), Jan Walc. Biografia opozycjonisty (2018), Podziemne dziennikarstwo (2018) i Podziemna sieć społeczna (2020). Co-author of Holokaust, pamięć, powielacz (2020). 